\title{
Mineralogical Distribution of Germanium, Gallium and Indium at the Mt Carlton High-Sulfidation Epithermal Deposit, NE Australia, and Comparison with Similar Deposits Worldwide
}

\author{
Fredrik Sahlström ${ }^{1}{ }^{*}$, Antonio Arribas ${ }^{2}$, Paul Dirks ${ }^{1}$ (D), Isaac Corral ${ }^{1}$ and Zhaoshan Chang ${ }^{1}$ \\ 1 Economic Geology Research Centre (EGRU) and Academic Group of Geosciences, \\ College of Science and Engineering, James Cook University, Townsville, QLD 4811, Australia; \\ paul.dirks@jcu.edu.au (P.D.); isaac.corralcalleja@jcu.edu.au (I.C.); zhaoshan.chang@jcu.edu.au (Z.C.) \\ 2 International Center for Research and Education on Mineral and Energy Resources (ICREMER), \\ Akita University, Akita 010-8502, Japan; arribasa@yahoo.com \\ * Correspondence: fredrik.sahlstrom@my.jcu.edu.au
}

Received: 13 October 2017; Accepted: 31 October 2017; Published: 5 November 2017

\begin{abstract}
Germanium, gallium and indium are in high demand due to their growing usage in high-tech and green-tech applications. However, the mineralogy and the mechanisms of concentration of these critical elements in different types of hydrothermal ore deposits remain poorly constrained. We investigated the mineralogical distribution of Ge, Ga and In at the Mt Carlton high-sulfidation epithermal deposit in NE Australia, using electron probe microanalysis and laser ablation inductively-coupled plasma mass spectrometry. Parageneses from which selected minerals were analyzed include: Stage 1 acid sulfate alteration (alunite), Stage 2A high-sulfidation enargite mineralization (enargite, argyrodite, sphalerite, pyrite, barite), Stage 2B intermediate-sulfidation sphalerite mineralization (sphalerite, pyrite, galena) and Stage 3 hydrothermal void fill (dickite). Moderate to locally high concentrations of Ga were measured in Stage 1 alunite (up to $339 \mathrm{ppm}$ ) and in Stage 3 dickite (up to $150 \mathrm{ppm}$ ). The Stage 2A ores show enrichment in Ge, which is primarily associated with argyrodite (up to $6.95 \mathrm{wt} \% \mathrm{Ge}$ ) and Ge-bearing enargite (up to $2189 \mathrm{ppm} \mathrm{Ge}$ ). Co-existing sphalerite has comparatively low Ge content (up to $143 \mathrm{ppm}$ ), while Ga (up to $1181 \mathrm{ppm}$ ) and In (up to $571 \mathrm{ppm}$ ) are higher. Sphalerite in Stage 2B contains up to $611 \mathrm{ppm} \mathrm{Ge,} 2829 \mathrm{ppm}$ Ga and 2169 ppm In, and locally exhibits fine colloform bands of an uncharacterized Zn-In mineral with compositions close to $\mathrm{CuZn}_{2}(\mathrm{In}, \mathrm{Ga}) \mathrm{S}_{4}$. Barite, pyrite and galena which occur in association with Stage 2 mineralization were found to play negligible roles as carriers of $\mathrm{Ge}, \mathrm{Ga}$ and In at Mt Carlton. Analyzed reference samples of enargite from seven similar deposits worldwide have average Ge concentrations ranging from 12 to $717 \mathrm{ppm}$ (maximum $2679 \mathrm{ppm}$ ). The deposits from which samples showed high enrichment in critical elements in this study are all hosted in stratigraphic sequences that locally contain carbonaceous sedimentary rocks. In addition to magmatic-hydrothermal processes, such rocks could potentially be important for the concentration of critical elements in high-sulfidation epithermal deposits.
\end{abstract}

Keywords: Mt Carlton; high-sulfidation; epithermal; germanium; gallium; indium; critical elements; LA-ICP-MS; enargite; sphalerite

\section{Introduction}

Germanium (Ge), gallium (Ga) and indium (In) are three commodities which have become increasingly sought-after in recent years. This is largely due to their growing usage in various high-tech and green-tech applications, such as smartphones (Ga, In), optoelectronics (Ge, Ga, In), fiber 
optics (Ge) and solar cells (Ge, Ga, In) [1-5]. Due to their increasing economic importance combined with current supply security risks, Ge, Ga and In are commonly classified within the group of critical raw materials [6]. These elements can be concentrated in a variety of hydrothermal ore deposits, including volcanic hosted massive sulfide (VHMS) deposits, Mississippi Valley-type (MVT) deposits, carbonate-hosted polymetallic deposits of Tsumeb-type (exemplified by Tsumeb in Namibia, Kipushi in D.R. Congo and the Apex Mine in Utah; e.g., [7]), syngenetic or early diagenetic sedimentary exhalative (SEDEX) deposits, epithermal deposits, polymetallic $( \pm S n)$ vein or stockwork deposits linked to granites, and skarn deposits $[1,7,8]$. Although Ge, Ga and In may form their own independent minerals, they are also incorporated as trace components into various minerals $[1,7,9,10]$. There are no hydrothermal ore deposits that are mined primarily for these elements. Instead, recovery of Ge, Ga and In occur as by-products from operations for other commodities, chiefly from the processing of sphalerite ores [1,2,11-14]. Enrichment in Ge and Ga in sphalerite is generally favored in low-temperature deposits that are not necessarily related to magmatic fluid (e.g., MVT deposits; $[2,10,13,14]$ ). Indium on the other hand is strongly linked to relatively high-temperature magmatic-hydrothermal systems, often related to felsic intrusions $[10,15,16]$.

High-sulfidation epithermal (HS) $\mathrm{Au} \pm \mathrm{Ag}-\mathrm{Cu}$ deposits occur in calc-alkaline island and continental arcs related to subduction zones $[17,18]$. These deposits are believed to form in a magmatic-hydrothermal environment equivalent to that beneath modern volcanic fumaroles and crater lakes [19]. Mineralization styles include hydrothermal breccias, veins, stockworks, and disseminations or replacements [20]. The high-grade ore typically occurs within cores of residual silica alteration, which reflect the leaching effects of highly acidic magmatic vapor condensates. The silicic cores are enveloped by a laterally extensive zone of advanced argillic alteration, and together they form a subhorizontal blanket, or lithocap, above the mineralizing intrusion [21-24]. A distinguishing feature of HS deposits is a high-sulfidation state ore mineral assemblage dominated by enargite and pyrite $[20,25,26]$. Most HS deposits also contain a later-stage ore mineral assemblage that is Au-rich and comprises intermediate-sulfidation state minerals (e.g., chalcopyrite, pyrite, tennantite-tetrahedrite, sphalerite, galena, electrum, and tellurides) [20,26,27]. High-sulfidation epithermal deposits and their associated lithocaps have a spatial and genetic link to porphyry $\mathrm{Cu}$ deposits (occurring in and around magmatic apophyses from the causative intrusion), intermediate-sulfidation epithermal (IS) deposits (commonly occurring on the flanks of the lithocap) and skarn deposits (occurring in carbonate-bearing wall rocks, if present) $[23,24,28,29]$. Mineralization in IS deposits shows close similarities to that in HS deposits except that the enargite-bearing assemblage is lacking, the Ag:Au ratio is typically higher, and advanced argillic assemblages form a smaller proportion of the wall rock alteration facies [26]. Despite major advances in the understanding of porphyry-epithermal mineral systems in recent decades, relatively little work has been done on the presence and distribution of critical elements such as Ge, Ga and In in these deposits.

The northern Bowen Basin is a metallogenic province related to Permocarboniferous magmatism in NE Queensland, Australia. Here, a variety of porphyry and epithermal mineral occurrences are hosted within an Early Permian backarc rift sequence (Figure 1; [30]). The most significant deposit in the northern Bowen Basin, and the only one currently in production, is the Mt Carlton HS deposit. Mt Carlton was discovered in 2006, and as of December 2016 it was estimated to contain a resource of $10.42 \mathrm{Mt}$ averaging $2.92 \mathrm{~g} / \mathrm{t} \mathrm{Au}, 30.60 \mathrm{~g} / \mathrm{t} \mathrm{Ag}$ and $0.47 \% \mathrm{Cu}$ [30]. An active open pit operation includes the Au-rich V2 pit in the NE, and the Ag-rich A39 pit in the SW (Figure 2). Mt Carlton represents one of the world's few economic pre-Neogene HS deposits, and it formed during a stage of backarc rifting as the laterally extensive Bowen Basin was opening in the Early Permian [30].

In this study, we use electron probe microanalysis (EPMA) and laser ablation inductively-coupled plasma mass spectrometry (LA-ICP-MS) to determine the concentrations and distribution of Ge, Ga and In and related elements in key minerals formed throughout the paragenetic sequence at Mt Carlton. Samples from a selection of global HS and porphyry deposits are analyzed for reference, and the results are compared with available case studies from the literature. The main aim of the study is to improve 
the understanding of the mineralogical distribution of Ge, Ga and In in HS deposits. This information is a pre-requisite for the evaluation of HS deposits as potential sources for these elements, and for the development of efficient ore processing methods during recovery.

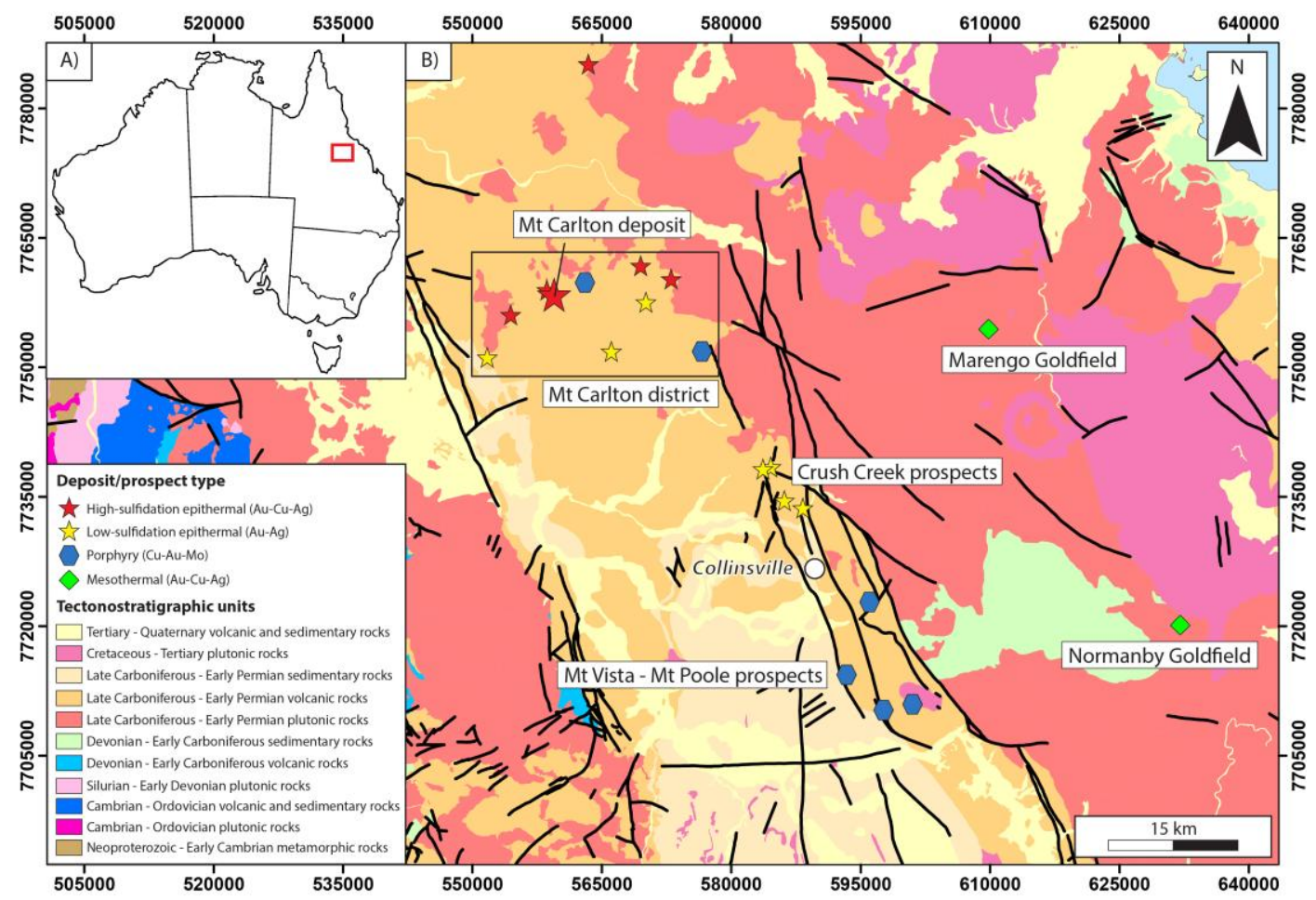

Figure 1. (A) Location of the northern Bowen Basin (red rectangle) in NE Queensland, Australia. (B) Geologic map of the northern Bowen Basin (center of map) and the corresponding Connors Arc (right-hand side of map), showing the location of the known porphyry, epithermal and mesothermal mineral occurrences. Grid-UTM zone 55; datum-GDA94. From Sahlström et al. [30].

\section{Geologic Setting of the Mt Carlton Deposit}

\subsection{Regional Geology}

The Bowen Basin is a NW-trending elongate sedimentary basin located in eastern Queensland, Australia. It formed as part of the New England Orogen during the Early Permian to Middle Triassic, and shows evidence for a complex and polyphase tectonic evolution ([31], and references therein). Backarc rifting in the Bowen Basin was initiated in the Early Permian, and resulted in a series of isolated graben and half graben basins infilled with volcanic and sedimentary rocks [32-34]. The Lizzie Creek Volcanic Group formed during this stage, and is the principal host of mineralization in the northern Bowen Basin. Thermal relaxation took over as the dominant mechanism of subsidence in the Middle Permian. This led to widespread transgression and deposition of marine, coastal plain and carbonate sedimentary units (e.g., the Back Creek Group and Tiverton Formation; [33,35-37]). The thermal relaxation stage was abruptly terminated in the Late Permian, due to the progression of a series of inland-stepping orogenic fronts during the 265-235 Ma Hunter-Bowen Orogeny ([31], and references therein). This caused foreland loading, tectonic inversion and the development of a foreland basin. The foreland basin stage involved voluminous deposition of terrestrial sediments (e.g., the Blackwater Group) and coal measures (e.g., the Moranbah-German Creek CM and Rangal CM) until the Bowen Basin closed in the Middle Triassic [33,38-40]. 


\subsection{Stratigraphy and Deformation Sequence at Mt Carlton}

The basement in the northern Bowen Basin consists of fine- to medium-grained I-type granitoids belonging to the Urannah Batholith. At Mt Carlton, the granite basement (Unit 1, 297-294 Ma; [41]) is overlain by a volcano-sedimentary sequence belonging to the Early Permian Lizzie Creek Volcanic Group (288-275 Ma; [41]). The Lizzie Creek sequence consists of (from bottom to top): fine-grained porphyritic andesite (Unit 2), massive and locally flowbanded porphyritic rhyodacite (Unit 3), well-bedded fragmental rhyodacite lapilli tuffs with interbedded carbonaceous lacustrine sediments (Unit 4A), massively bedded dacite tuffs (Unit 4B), fragmental to agglomeritic dacite (Unit 5), fragmental to agglomeritic andesite and minor andesite lava (Unit 6), water-laid sediments with local coal seams (Unit 7), and a flowbanded rhyolite unit (Unit 8) forming the top of the sequence [30]. Mineralization at Mt Carlton is hosted partly in the massive rhyodacite porphyry (Unit 3) and partly in the overlying volcano-lacustrine sediments (Unit 4A; Figure 2).

The Mt Carlton deposit has experienced five stages of extensional deformation [30]. Hydrothermal alteration and subsequent epithermal mineralization occurred during a stage of rifting with associated high-angle normal faulting in response to both E-W and N-S extension $\left(\mathrm{D}_{1}\right)$. Mineralization was controlled by steep normal faults and fracture networks related to the rifting, and occurred partly contemporaneously with volcanism and deposition of volcanic sediments into local graben and half graben basins. Continued E-W extension after mineralization provided rapid burial of the Mt Carlton deposit beneath a volcano-sedimentary cover. It also caused the development of a series of low-angle (and locally layer-parallel) detachment faults which have rotated and displaced the stratigraphic sequence and the ore zones at Mt Carlton $\left(\mathrm{D}_{2}\right)$. High-angle normal faulting in response to N-S extension and emplacement of E-W trending basaltic dykes into the normal faults $\left(\mathrm{D}_{3}\right)$ was followed by dominantly dextral strike-slip faulting along the dyke margins $\left(\mathrm{D}_{4}\right)$. A final stage involving emplacement of WNW-trending basaltic dykes $\left(\mathrm{D}_{5}\right)$ completes the deformation sequence at Mt Carlton.

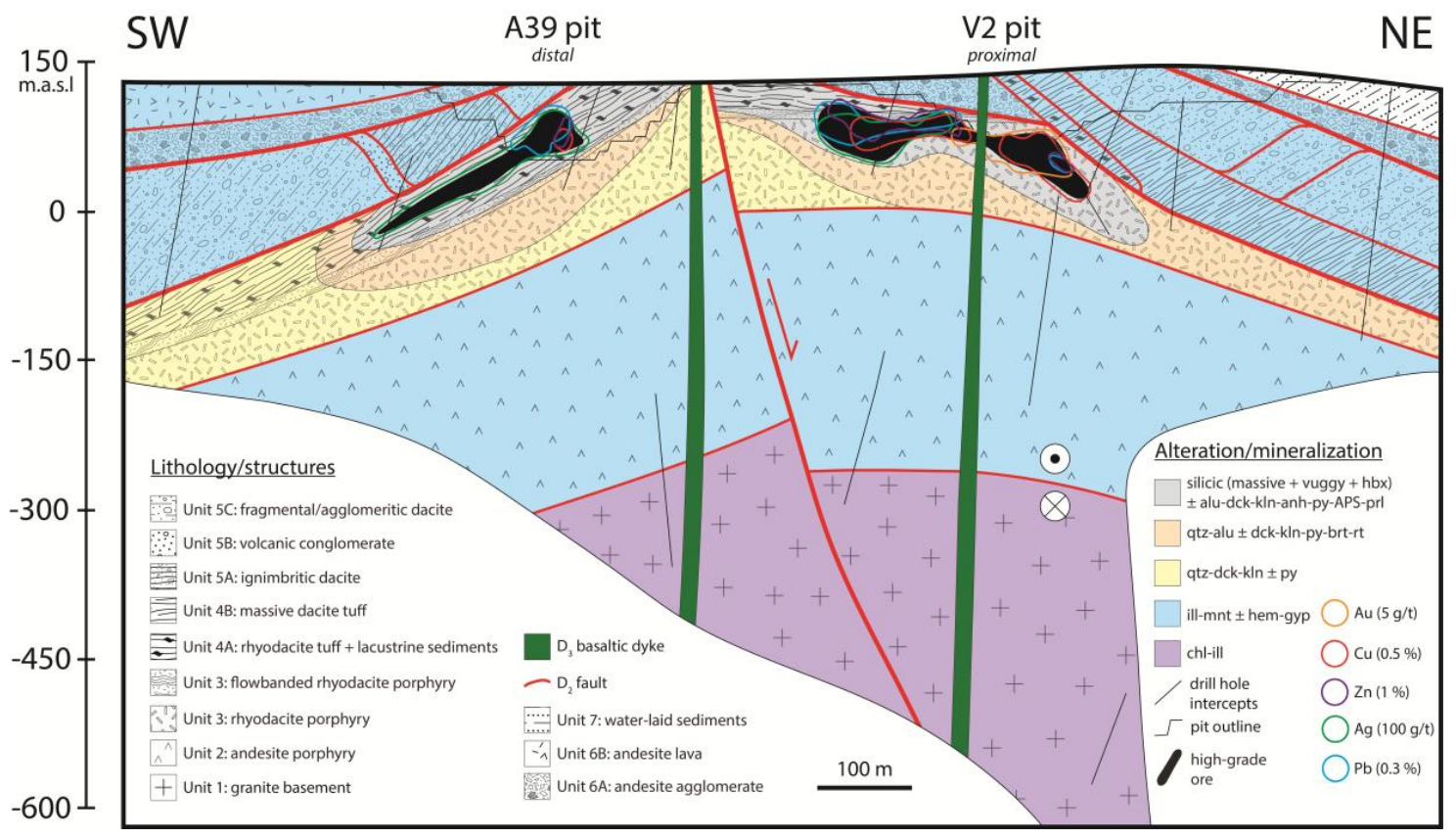

Figure 2. NE-SW section along the Western ore zone at Mt Carlton. The section shows the distribution of stratigraphic units, major $\mathrm{D}_{2}$ structures, alteration assemblages and high-grade mineralization. Abbreviations: alu—alunite; anh—anhydrite; APS—aluminium-phosphate-sulphate minerals; brt-barite; chl—chlorite; dck-dickite; gyp-gypsum; hbx-hydrothermal breccia; hem-hematite; ill—illite; kln—kaolinite; mnt-montmorillonite; prl—pyrophyllite; py-pyrite; qtz-quartz; rt—rutile. Modified from Sahlström et al. [30]. 


\section{Mineral Paragenesis}

\subsection{Hydrothermal Alteration}

The volcano-sedimentary host rocks at Mt Carlton are extensively hydrothermally altered. Stage 1A of the paragenetic sequence (Figure 3) comprises a suite of magmatic-hydrothermal alteration assemblages that are zoned outward, away from fluid conduits as follows: silicic (massive + vuggy + hydrothermal breccia) $\rightarrow$ quartz-alunite (Figure 4A) $\rightarrow$ quartz-dickite-kaolinite. This alteration halo envelops mineralization in Units 3 and $4 \mathrm{~A}$ (Figure 2). The silicic cores locally contain veins and void fill made up of magmatic-steam alunite (Stage 1B; Figures 3 and 4B). Stage 1A alteration in the granite basement comprises chlorite and illite occurring in veinlets and as replacements of pre-existing phenocrysts of feldspar, biotite and hornblende.

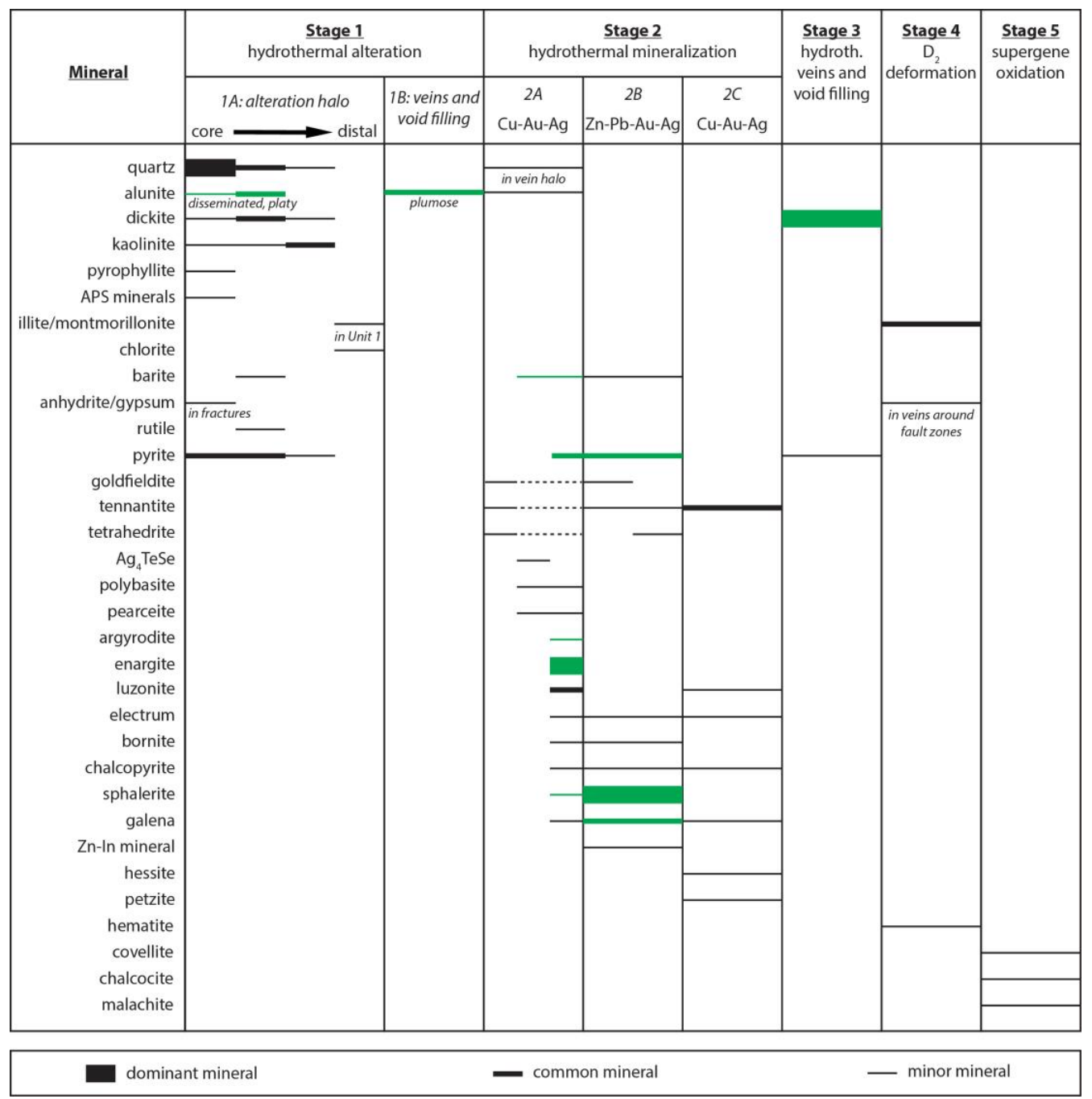

Figure 3. Paragenetic sequence of minerals at Mt Carlton. The minerals investigated in this study are highlighted in green. Modified from Sahlström et al. [30].

\subsection{Hydrothermal Mineralization and Void Fill}

Proximal $\mathrm{Au}-\mathrm{Cu}$ mineralization in the V2 pit occurs in networks of steep veins, fractures and hydrothermal breccia bodies in the rhyodacite porphyry (Unit 3). Three major ore zones (Eastern, Western and Link) are aligned in an en echelon fashion along an E-W trending corridor. The Eastern and Link ore zones terminate in the V2 pit, whereas the Western ore zone continues along $600 \mathrm{~m}$ 
strike length to the SW into the A39 pit. From proximal and deep to distal and shallow (at the time of formation), the Western ore zone shows a metal zonation of: $\mathrm{Au}-\mathrm{Cu} \rightarrow \mathrm{Cu}-\mathrm{Zn}-\mathrm{Pb}-\mathrm{Ag} \rightarrow \mathrm{Ag}-\mathrm{Pb}-(\mathrm{Cu})$ $\rightarrow \mathrm{Ag}$ (Figure 2). Distal Ag mineralization in the A39 pit occurs in the overlying volcano-lacustrine sediments (Unit 4A), in a stratiform position parallel to primary sedimentary layering [30].

Epithermal mineralization at Mt Carlton developed in three stages (Stages 2A-C; Figure 3). The initial Stage 2A mineralization is the most voluminous event, and comprises a high-sulfidation state mineral assemblage dominated by enargite. The assemblage also contains variable amounts of pyrite, luzonite, fahlores of tennantite-tetrahedrite-goldfieldite compositions, electrum, chalcopyrite, bornite, sphalerite, galena, argyrodite, pearceite-polybasite group minerals, an uncharacterized analogue to aguilarite and cervelleite [ideally $\mathrm{Ag}_{4} \mathrm{TeSe}$, and barite (Figure 3, Figure 4B-F and Figure 5C,D). Stage 2A mineralization is associated with silicic alteration (quartz \pm alunite) of the wall rocks (Figure $4 \mathrm{C}$ ). Whole rock analyses of Stage 2A ore samples from the V2 pit showed average concentrations of $61 \mathrm{ppm}$ Ge (up to $246 \mathrm{ppm}$ ), $34 \mathrm{ppm} \mathrm{Ga} \mathrm{(up} \mathrm{to} 66 \mathrm{ppm}$ ) and $56 \mathrm{ppm}$ In (up to $151 \mathrm{ppm} \mathrm{In),} \mathrm{while} \mathrm{samples} \mathrm{from}$ the A39 pit yielded average concentrations of 109 ppm Ge (up to $342 \mathrm{ppm}$ ), $24 \mathrm{ppm} \mathrm{Ga}$ (up to $45 \mathrm{ppm}$ ) and $11 \mathrm{ppm}$ In (up to $19 \mathrm{ppm}$ ) [30].

Stage 2A mineralization is crosscut by a younger intermediate-sulfidation state mineral assemblage dominated by sphalerite (Stage 2B). The Stage 2B assemblage also contains variable amounts of galena, pyrite, electrum, fahlores of tennantite-tetrahedrite-goldfieldite compositions, chalcopyrite, bornite and barite (Figures 3, 4D and 5E). Sahlström et al. [42] recently documented the presence of a mineral with compositions close to $\mathrm{CuZn}_{2}(\mathrm{In}, \mathrm{Ga}) \mathrm{S}_{4}$, which occurs as fine $(\sim 1 \mu \mathrm{m}$ thick) colloform bands inside the Stage $2 \mathrm{~B}$ sphalerite (Figure $5 \mathrm{~F}$, Table 1 ). This mineral corresponds to a Ga-rich variety of the uncharacterized $\mathrm{Zn}$-In mineral [ideally $\mathrm{CuZn}_{2} \mathrm{InS}_{4}$ ] first described from the Toyoha deposit in Japan [43], and later from the Mt Pleasant deposit in Canada [44]. Stage 2B ore samples from the V2 pit showed average whole rock concentrations of $167 \mathrm{ppm}$ Ge (up to $265 \mathrm{ppm}$ ), $284 \mathrm{ppm}$ Ga (up to $396 \mathrm{ppm}$ ) and $255 \mathrm{ppm}$ In (up to $408 \mathrm{ppm}$ ), while average concentrations of $7 \mathrm{ppm} \mathrm{Ge} \mathrm{(up} \mathrm{to} 13 \mathrm{ppm}$ ), $108 \mathrm{ppm} \mathrm{Ga}$ (up to $151 \mathrm{ppm}$ ) and $201 \mathrm{ppm}$ In (up to $468 \mathrm{ppm}$ ) were observed for samples from the A39 pit [30].

Table 1. List of critical element-bearing minerals identified at the Mt Carlton deposit.

\begin{tabular}{|c|c|c|c|c|c|c|}
\hline Mineral & Class & Crystal System & Ideal Formula & Paragenesis & $\begin{array}{l}\text { Contained } \\
\text { Elements }\end{array}$ & Reference \\
\hline Alunite & Sulfate & Trigonal & $\mathrm{KAl}_{3}\left(\mathrm{SO}_{4}\right)_{2}(\mathrm{OH})_{6}$ & $1 \mathrm{~A}$ and $1 \mathrm{~B}$ & $\mathrm{Ga}$ & this study \\
\hline Argyrodite & Sulfide & Orthorhombic & $\mathrm{Ag}_{8} \mathrm{GeS}_{6}$ & $2 \mathrm{~A}$ & $\mathrm{Ge}$ & this study \\
\hline Enargite & Sulfosalt & Orthorhombic & $\mathrm{Cu}_{3} \mathrm{AsS}_{4}$ & $2 \mathrm{~A}$ & $\mathrm{Ge}(\mathrm{In}, \mathrm{Ga})$ & this study \\
\hline Sphalerite & Sulfide & Isometric & $\mathrm{ZnS}$ & $2 \mathrm{~A}$ and $2 \mathrm{~B}$ & In, Ga, Ge & this study \\
\hline Zn-In mineral & Sulfide & Uncharacterized & $\mathrm{CuZn} \mathrm{InS}_{4}$ & $2 \mathrm{~B}$ & $\mathrm{In}, \mathrm{Ga}$ & [42] \\
\hline Dickite & Silicate & Monoclinic & $\mathrm{Al}_{2} \mathrm{Si}_{2} \mathrm{O}_{5}(\mathrm{OH})_{4}$ & 3 & $\mathrm{Ga}$ & this study \\
\hline
\end{tabular}

Stage $2 \mathrm{C}$ is a minor event that overprinted Stage $2 \mathrm{~B}$ mineralization, and it has only been observed at the microscopic scale. The mineral assemblage is of intermediate-sulfidation state and is dominated by tennantite. The tennantite forms anhedral masses that contain variable amounts of luzonite, chalcopyrite, galena, electrum and aggregates of intergrown hessite and petzite (Figure 3). A late stage of dickite and pyrite (Stage 3; Figures 3 and $4 \mathrm{~F}$ ) is prevalent at Mt Carlton and occurs in veins and as massive void fill overprinting Stage 2 mineralization.

\subsection{Syn-Tectonic Alteration and Supergene Oxidation}

Pervasive illite-montmorillonite \pm red hematite alteration with local syn-tectonic gypsum veins developed regionally during the $\mathrm{D}_{2}$ deformation event (Stage 4; Figure 3). In the area around the open pits, this alteration affects Units 2, 5 and 6, and locally Unit 4 (Figure 2). The final paragenetic stage at Mt Carlton involves minor degrees of supergene oxidation that affects the upper $\sim 50 \mathrm{~m}$ of the deposit. This has caused local development of secondary covellite, chalcocite and malachite on $\mathrm{Cu}$-bearing minerals such as enargite, luzonite and bornite, particularly along fractures within the minerals (Stage 5; Figures 3 and 5E). 

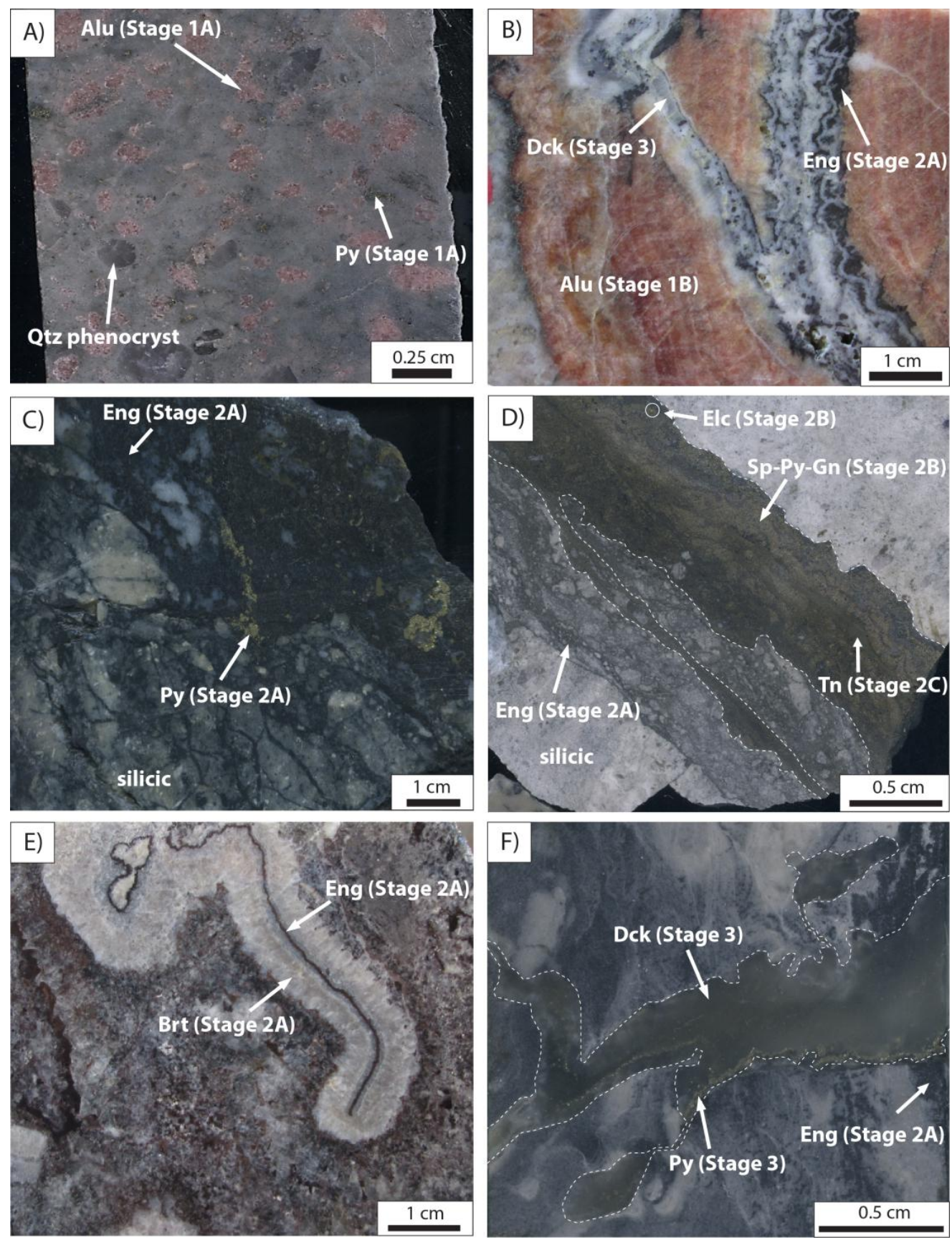

Figure 4. Photographs of relevant alteration and mineralization assemblages from Mt Carlton. (A) Quartz-alunite-pyrite alteration (Stage 1A) developed in a quartz-feldspar phyric rhyodacite. Magmatic-hydrothermal alunite occurs as disseminations and as replacements of pre-existing feldspars. (B) Plumose alunite vein of magmatic-steam origin (Stage 1B). After deposition of alunite, the vein was re-opened along the central line to form an enargite vein (Stage $2 \mathrm{~A}$ ). The composite vein was then overprinted by dickite (Stage 3). (C) Silicic hydrothermal breccia cemented by Stage 2A enargite-pyrite ore. (D) Silicic altered rhyodacite crosscut by a fine enargite-cemented hydrothermal breccia (Stage 2A). The enargite breccia is crosscut by a sphalerite-pyrite-galena vein containing specules of electrum (Stage 2B). The sphalerite vein is in turn locally overprinted by tennantite (Stage 2C). (E) Stage 2A enargite veinlet with a halo of barite. (F) Disseminated Stage 2A enargite mineralization crosscut by a Stage 3 dickite-pyrite vein. Mineral abbreviations: Alu—alunite; Brt-barite; Dck—dickite; Elc—electrum; Eng—enargite; Gn—galena; Py—pyrite; Qtz-quartz; Sp—sphalerite; Tn—tennantite. 

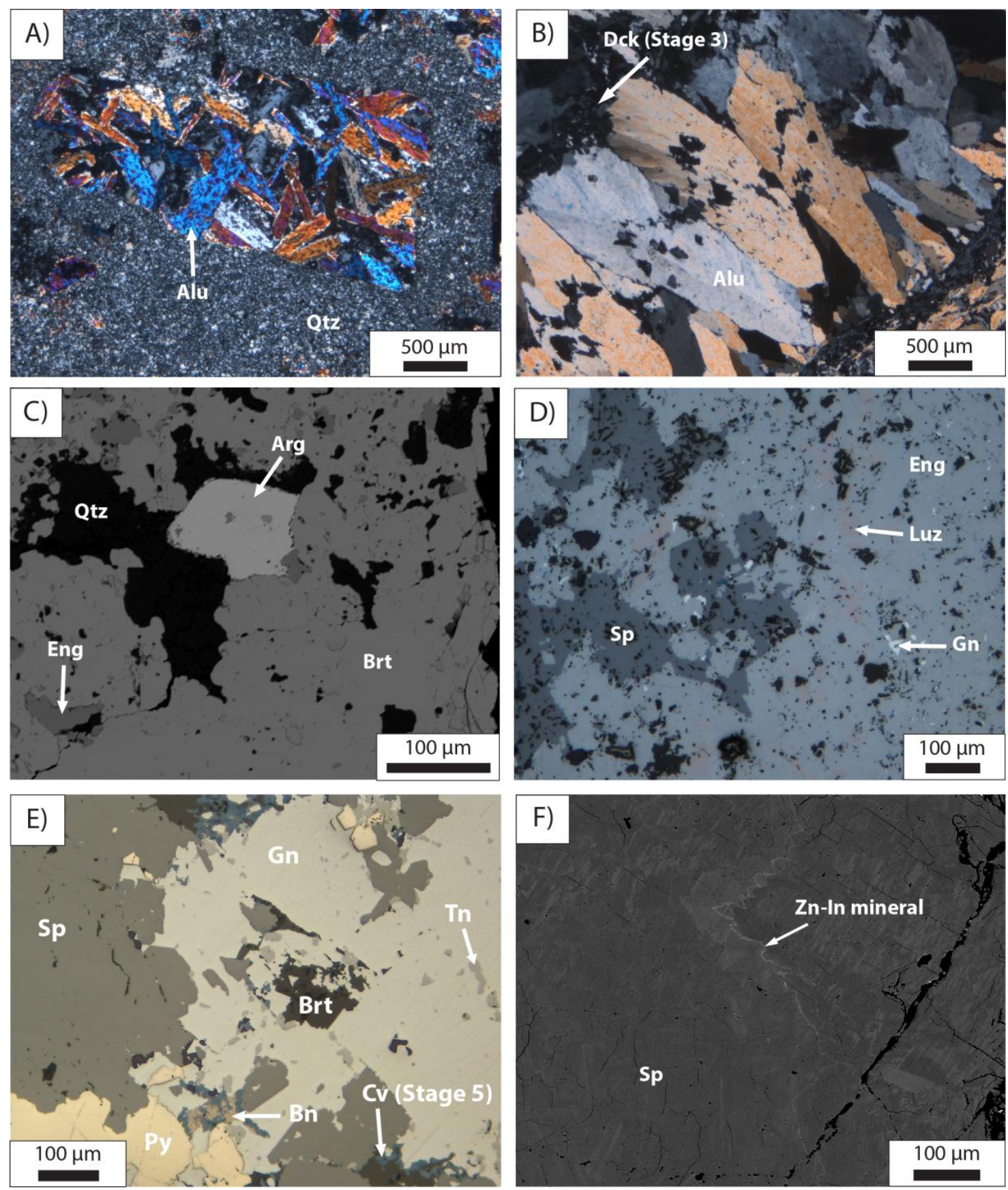

Figure 5. Associations of minerals investigated in this study. (A) Magmatic-hydrothermal alunite (Stage 1A) replacing a pre-existing feldspar crystal in a quartz-feldspar phyric rhyodacite (transmitted light, cross polarized). (B) Plumose texture in a magmatic-steam alunite vein (Stage 1B). Alunite is locally overprinted by Stage 3 dickite (transmitted light, cross polarized). (C) Argyrodite intergrown with barite and enargite in Stage 2A high-sulfidation ore (BSE image). (D) Stage 2A high-sulfidation assemblage comprising enargite, luzonite, sphalerite and galena (reflected light, plane polarized). (E) Stage 2B assemblage comprising sphalerite, pyrite, galena, bornite and barite. The galena contains abundant segregations of tennantite. Stage 5 covellite has locally overprinted the assemblage (reflected light, plane polarized). (F) Colloform texture in Stage 2B sphalerite. The fine BSE-bright band corresponds to the $\mathrm{Zn}$-In mineral $\left[\mathrm{CuZn}{ }_{2}(\mathrm{In}, \mathrm{Ga}) \mathrm{S}_{4}\right]$ (BSE image). Mineral abbreviations: Alu—alunite; Arg-argyrodite; Bn—bornite; Brt—barite; Cv—covellite; Dck—dickite; Eng-enargite; Gn—galena; Luz-luzonite; Qtz-quartz; Sp—sphalerite; Tn—tennantite. 


\section{Methods}

\subsection{Sampling}

The samples used in this study were collected from drill cores and in situ from outcrops in the open pits at Mt Carlton, and subsequently prepared as polished thin and thick sections. The present study focuses on key minerals formed throughout the paragenetic sequence at Mt Carlton, including minerals formed during Stage 1 acid sulfate alteration (alunite), Stage 2A high-sulfidation mineralization (enargite, argyrodite, sphalerite, pyrite and barite), Stage 2B intermediate-sulfidation mineralization (sphalerite, pyrite and galena) and Stage 3 hydrothermal void fill (dickite) (Figure 3 and Table 1). Analytical measurements were generally conducted on multiple samples to obtain a range of representative results, and when possible, samples from both the V2 pit (proximal) and the A39 pit (distal) were included.

Despite enargite being the principal ore mineral in HS deposits there is a lack of published trace element data for this mineral, in particular with regards to its content of $\mathrm{Ge}, \mathrm{Ga}$ and In. Therefore we have also included reference samples of enargite from seven representative HS and porphyry deposits around the world. These samples were collected during previous field visits to the deposits, and include Lepanto (Philippines), Laurani (Bolivia), La Mejicana (Argentina), Motomboto (Indonesia), Chelopech (Bulgaria), Cerro Quema (Panama) and El Salvador (Chile) (Table 2).

\subsection{WDS Spot Analyses}

The major element composition of argyrodite was determined by wavelength dispersive spectroscopy (WDS) using a Jeol JXA8200 "Superprobe" (Jeol, Tokyo, Japan) housed at the Advanced Analytical Centre (AAC) at James Cook University. Analyses were done utilizing a focused beam $(<1 \mu \mathrm{m})$ with an accelerating voltage of $20 \mathrm{kV}$ and a beam current of $20 \mathrm{nA}$. Analytical conditions were [analyzed element (standard, line, crystal)]: $\mathrm{Cu}$ (chalcopyrite, $\mathrm{K} \alpha, \mathrm{LIF}), \mathrm{S}$ (chalcopyrite, K $\alpha, \mathrm{PET}$ ), $\mathrm{Pb}$ (galena, $\mathrm{M} \alpha, \mathrm{PET}$ ), Ag (argentite, $\mathrm{L} \alpha, \mathrm{PET}), \mathrm{Bi}$ (bismuthinite, $\mathrm{M} \alpha, \mathrm{PET}$ ), Se (bismuthinite, L $\alpha, \mathrm{TAP})$, As (gallium arsenide, $\mathrm{L} \alpha$, TAP), $\mathrm{Sb}$ (metal Sb, $\mathrm{L} \alpha, \mathrm{PET}$ ), Te (metal Te, L $\alpha, \mathrm{PET}), \mathrm{Au}$ (metal Au, M $\alpha$, PET) and Ge (metal Ge, K $\alpha$, LIF).

\subsection{WDS Element Mapping}

WDS element mapping of enargite was performed on the same electron microprobe, utilizing a $2 \mu \mathrm{m}$ electron beam with an accelerating voltage of $20 \mathrm{kV}$ and a beam current of $200 \mathrm{nA}$. Mapping was done with a step size of $2 \mu \mathrm{m}$ and a $100 \mathrm{~ms}$ dwell time. GeL $\alpha$ was measured on a TAP crystal, $\mathrm{ZnK} \alpha$ on a LIFH crystal, FeK $\alpha$ on a LIF crystal, SnL $\alpha$ on a PETJ crystal and SbL $\alpha$ on a PETJ crystal. Element maps were processed offline using the ImageJ software.

\subsection{LA-ICP-MS Spot Analyses}

Trace element analyses of alunite, enargite, pyrite, galena, sphalerite, barite and dickite were done in separate runs using a Varian 820 ICP-MS instrument (Varian, Melbourne, Australia) interfaced to a GeoLas 200M 193 nm ArF excimer laser ablation system (Coherent, Göttingen, Germany), housed at the AAC. Ablation was conducted in a custom built large volume cell using high-purity He as the carrier gas, which was subsequently mixed with Ar prior to introduction into the ICP-MS. For spot analyses, the laser fluence was generally $5-6 \mathrm{~J} / \mathrm{cm}^{2}$ at the sample site with the laser repetition rate set to $10 \mathrm{~Hz}$ and the beam diameter set to between 24 and $60 \mu \mathrm{m}$. 
Table 2. List of deposits from which reference samples of enargite were analyzed.

\begin{tabular}{|c|c|c|c|c|c|}
\hline Deposit & Type & Age & Tectonic Setting & Stratigraphic Column (excluding post-mineralization units) & Reference \\
\hline $\begin{array}{c}\text { Lepanto } \\
\text { (Philippines) }\end{array}$ & HS & Quarternary & Island arc & $\begin{array}{l}\text { Andesite-dacite pyroclastic rocks and porphyry intrusions (Imbanguila Dacite) } \\
\text { Andesite volcaniclastic rocks (Balili Volcaniclastics), intruded by a quartz-diorite porphyry complex } \\
\text { Basement of metamorphosed submarine basalt-andesite volcanic rocks (Lepanto metavolcanic rocks) }\end{array}$ & [29] \\
\hline $\begin{array}{l}\text { Laurani } \\
\text { (Bolivia) }\end{array}$ & HS & Neogene & $\begin{array}{l}\text { Continental arc } \\
\text { (foreland basin) }\end{array}$ & $\begin{array}{l}\text { Andesite-rhyolite lava and pyroclastic rocks (Laurani volcanic complex) } \\
\text { Red bed conglomerate, sandstone and siltstone (Chuquichambi Formation) } \\
\text { Basement comprising shale, siltstone and sandstone (Llalagua, Uncia and Catavi Formations) }\end{array}$ & [45] \\
\hline $\begin{array}{l}\text { La Mejicana } \\
\text { (Argentina) }\end{array}$ & HS & Neogene & Continental arc & $\begin{array}{l}\text { Dacite-rhyodacite porphyritic rocks (Mogote Formation) } \\
\text { Continental sandstone and conglomerate (Agua Colorada and Patquía Formations) } \\
\text { Basement of metamorphosed shale, sandstone, siltstone (Negro Peinado Formation), intruded by Nuñarco granites }\end{array}$ & [46] \\
\hline $\begin{array}{l}\text { Motomboto } \\
\text { (Indonesia) }\end{array}$ & HS & Quarternary & Island arc & $\begin{array}{c}\text { Subaerial andesite-rhyolite lava and pyroclastic rocks (Motomboto Volcanics) } \\
\text { Submarine basalt-andesite lava (Bilungala Volcanics) } \\
\text { Unknown basement }\end{array}$ & [47] \\
\hline $\begin{array}{l}\text { Chelopech } \\
\text { (Bulgaria) }\end{array}$ & HS & Cretaceous & Island arc & $\begin{array}{c}\text { Argillaceous limestone, calcarenite and sandstone interlayered with volcanic rocks (Chelopech Formation) } \\
\text { Coal-bearing conglomerate and sandstone, intruded by subvolcanic andesite intrusions } \\
\text { Metamorphic basement comprising migmatitic gneiss, amfibolite, phillite }\end{array}$ & [48] \\
\hline $\begin{array}{l}\text { Cerro Quema } \\
\text { (Panama) }\end{array}$ & HS & Paleogene & $\begin{array}{c}\text { Island arc } \\
\text { (forearc basin) }\end{array}$ & $\begin{array}{c}\text { Andesite-dacite volcanic rocks, biomicritic hemipelagic limestone, turbidite, shale (Río Quema Formation) } \\
\text { Basement comprising basalt and pillow basalt (Azuero Igneous Basement) }\end{array}$ & [49] \\
\hline $\begin{array}{l}\text { El Salvador } \\
\text { (Chile) }\end{array}$ & Porphyry & Paleogene & Continental arc & $\begin{array}{c}\text { Rhyolite dome complex (Indio Muerto Rhyolite), intruded by rhyolite and granodiorite porphyry complexes } \\
\text { Basement comprising andesite lava and volcaniclastic rocks }\end{array}$ & {$[50]$} \\
\hline
\end{tabular}


The primary purpose of the LA-ICP-MS analyses was to determine whether the investigated minerals have low (e.g., $<10$ ppm), moderate (e.g., 10-100 ppm) or high (e.g., >100 ppm) concentrations of $\mathrm{Ge}, \mathrm{Ga}$ and In. The minerals differ significantly in their structure and major element composition, and thus, in which trace elements they can be expected to incorporate. We used two separate analytical protocols for sulfates/silicates and sulfides/sulfosalts, respectively. For alunite, barite and dickite, the collected analytes were ${ }^{27} \mathrm{Al},{ }^{31} \mathrm{P},{ }^{44} \mathrm{Ca},{ }^{49} \mathrm{Ti},{ }^{53} \mathrm{Cr},{ }^{55} \mathrm{Mn},{ }^{57} \mathrm{Fe},{ }^{65} \mathrm{Cu},{ }^{66} \mathrm{Zn},{ }^{71} \mathrm{Ga},{ }^{72} \mathrm{Ge},{ }^{75} \mathrm{As},{ }^{77} \mathrm{Se},{ }^{85} \mathrm{Rb}$, ${ }^{88} \mathrm{Sr},{ }^{98} \mathrm{Mo},{ }^{107} \mathrm{Ag},{ }^{115} \mathrm{In},{ }^{118} \mathrm{Sn},{ }^{121} \mathrm{Sb},{ }^{137} \mathrm{Ba},{ }^{139} \mathrm{La},{ }^{140} \mathrm{Ce},{ }^{197} \mathrm{Au},{ }^{208} \mathrm{~Pb},{ }^{209} \mathrm{Bi},{ }^{232} \mathrm{Th}$ and ${ }^{238} \mathrm{U}$. The internal standard isotopes used for data reduction were ${ }^{27} \mathrm{Al}$ (alunite and dickite) and ${ }^{137} \mathrm{Ba}$ (barite), based on contents confirmed previously by WDS. NIST-SRM-610 [51] was used as a bracketing external standard, and GSE-1G and GSD-1G [52] were analyzed as secondary standards to evaluate accuracy. For enargite, sphalerite, pyrite and galena, the collected analytes were ${ }^{51} \mathrm{~V},{ }^{52} \mathrm{Cr},{ }^{55} \mathrm{Mn},{ }^{57} \mathrm{Fe},{ }^{59} \mathrm{Co},{ }^{60} \mathrm{Ni}$, ${ }^{65} \mathrm{Cu},{ }^{66} \mathrm{Zn},{ }^{71} \mathrm{Ga},{ }^{72} \mathrm{Ge},{ }^{75} \mathrm{As},{ }^{77} \mathrm{Se},{ }^{95} \mathrm{Mo},{ }^{107} \mathrm{Ag},{ }^{114} \mathrm{Cd},{ }^{115} \mathrm{In},{ }^{118} \mathrm{Sn},{ }^{121} \mathrm{Sb},{ }^{125} \mathrm{Te},{ }^{197} \mathrm{Au},{ }^{202} \mathrm{Hg},{ }^{205} \mathrm{Tl}$, ${ }^{208} \mathrm{~Pb}$ and ${ }^{209} \mathrm{Bi}$. USGS Mass-1 [53] was used as a bracketing external standard, and NIST-SRM-610, GSE-1G and GSD-1G were used as secondary standards. ${ }^{65} \mathrm{Cu}$ (enargite), ${ }^{66} \mathrm{Zn}$ (sphalerite), ${ }^{57} \mathrm{Fe}$ (pyrite) and ${ }^{208} \mathrm{~Pb}$ (galena) were used as the internal standard isotopes, based on contents confirmed previously by WDS.

Effort has been made to only report data reflecting elements hosted in solid solution within the studied minerals. Samples were inspected under the polarized light microscope and in backscatter electron (BSE) images prior to LA-ICP-MS analyses, so that only surfaces without visible mineral inclusions (and in the case of barite, fluid inclusions) were ablated. Segments in downhole spectra showing evidence for inclusions beneath the sample surface (i.e., sharp peaks in specific elements) were excluded during data processing, which was performed using the software GLITTER [54].

\section{Occurrence and Composition of Key Minerals at Mt Carlton}

\subsection{Alunite}

Alunite [trigonal $\mathrm{KAl}_{3}\left(\mathrm{SO}_{4}\right)_{2}(\mathrm{OH})_{6}$ ] occurs within the silicic and quartz-alunite alteration zones at Mt Carlton. Stage 1A magmatic-hydrothermal alunite $[55,56]$ comprises up to $\sim 300 \mu \mathrm{m}$ long euhedral, platy crystals occurring as disseminations, as infill in vugs, and as replacements of pre-existing feldspar crystals (Figures $4 \mathrm{~A}$ and $5 \mathrm{~A}$ ). Stage 1B magmatic-steam alunite $[55,56]$ occurs as coarse-grained, plumose and banded alunite in veins (Figures 4B and 5B). Previous WDS analyses of both types of alunite showed that they belong to the alunite-natroalunite solid solution series $\left[\mathrm{KAl}_{3}\left(\mathrm{SO}_{4}\right)_{2}(\mathrm{OH})_{6}-\mathrm{NaAl}_{3}\left(\mathrm{SO}_{4}\right)_{2}(\mathrm{OH})_{6}\right][30]$.

Trace element data was obtained for magmatic-hydrothermal alunite ( $\mathrm{n}=44,11$ samples) and magmatic-steam alunite ( $\mathrm{n}=21,3$ samples) from the V2 pit at Mt Carlton. Both types of alunite exhibit moderate to locally high concentrations of $\mathrm{Ga}$. The average Ga concentrations are $32 \mathrm{ppm}$ (up to $109 \mathrm{ppm}$ ) in magmatic-hydrothermal alunite and $72 \mathrm{ppm}$ (up to $339 \mathrm{ppm}$ ) in magmatic-steam alunite (Table 3, Supplementary Table S1). Gallium shows smooth downhole signals in alunite, suggesting it is hosted in solid solution. Furthermore, the signals of Ga closely match the signals of Al. Indeed, incorporation of Ga into minerals of the alunite supergroup is generally attributed to direct substitution of $\mathrm{Ga}^{3+}$ into the $\mathrm{G}$ site normally occupied by $\mathrm{Al}^{3+}$ or $\mathrm{Fe}^{3+}$ [57-60]. The concentrations of Ge and In in alunite were consistently below $10 \mathrm{ppm}$ and $2 \mathrm{ppm}$, respectively. Overall, magmatic-hydrothermal and magmatic-steam alunite display similar trace element signatures. Elements with average concentrations in excess of $100 \mathrm{ppm}$ include $\mathrm{P}, \mathrm{Ca}, \mathrm{Sr}, \mathrm{Ba}$ and $\mathrm{Pb}$ (both types), $\mathrm{Fe}$ (magmatic-hydrothermal alunite) and Ce (magmatic-steam alunite) (Table 3, Supplementary Table S1). 
Table 3. Summary table of LA-ICP-MS trace element compositions of minerals from Mt Carlton and similar deposits worldwide.

\begin{tabular}{|c|c|c|c|c|c|c|c|c|c|}
\hline Mineral & Location & Mineral Assemblage & n (Samples) & $\begin{array}{c}\text { Ge (ppm) } \\
\text { Mean (max) }\end{array}$ & $\begin{array}{c}\text { Ga (ppm) } \\
\text { Mean (max) }\end{array}$ & $\begin{array}{c}\text { In (ppm) } \\
\text { Mean (max) }\end{array}$ & $\begin{array}{c}\text { Au (ppm) } \\
\text { Mean (max) }\end{array}$ & $\begin{array}{l}\text { Other Elements } \\
\text { Mean }>1000 \text { ppm }\end{array}$ & $\begin{array}{l}\text { Other Elements } \\
\text { Mean }>100 \text { ppm }\end{array}$ \\
\hline \multicolumn{10}{|c|}{ Samples from Mt Carlton } \\
\hline Alunite & V2 pit & Stage $1 \mathrm{~A}$ & $44(11)$ & $1.2(9.1)$ & $32(109)$ & $0.1(1.3)$ & $0.0(0.2)$ & $\mathrm{Ba}$ & $\mathrm{P}, \mathrm{Ca}, \mathrm{Fe}, \mathrm{Sr}, \mathrm{Pb}$ \\
\hline Alunite & V2 pit & Stage 1B & $21(3)$ & $0.9(3.7)$ & $72(339)$ & $0.0(0.2)$ & $0.0(0.2)$ & $\mathrm{P}, \mathrm{Sr}$ & $\mathrm{Ca}, \mathrm{Ba}, \mathrm{Ce}, \mathrm{Pb}$ \\
\hline Enargite & V2 pit & Stage 2A & $14(2)$ & $86(330)$ & $6.0(37)$ & $14(155)$ & $12(62)$ & $\mathrm{Sb}, \mathrm{Bi}$ & $\mathrm{Fe}, \mathrm{Zn}, \mathrm{Se}, \mathrm{Ag}, \mathrm{Sn}, \mathrm{Te}$ \\
\hline Enargite & A39 pit & Stage 2A & $20(2)$ & $612(2189)$ & $5.2(35)$ & $7.7(76)$ & $0.2(1.4)$ & $\mathrm{Sb}$ & $\mathrm{Fe}, \mathrm{Zn}, \mathrm{Se}, \mathrm{Ag}, \mathrm{Te}, \mathrm{Pb}, \mathrm{Bi}$ \\
\hline Barite & A39 pit & Stage 2A & $53(4)$ & $0.3(1.8)$ & $0.4(1.4)$ & $0.0(0.0)$ & $0.0(0.0)$ & $\mathrm{Pb}, \mathrm{Sr}$ & $\mathrm{Ca}, \mathrm{La}, \mathrm{Ce}$ \\
\hline Pyrite & V2 pit & Stage $2 \mathrm{~A}$ & $14(2)$ & $3.5(4.7)$ & $0.2(0.4)$ & $0.1(0.2)$ & $2.4(11)$ & - & $\mathrm{Co}, \mathrm{Ni}, \mathrm{Cu}, \mathrm{Zn}, \mathrm{As}, \mathrm{Ag}$ \\
\hline Pyrite & V2 pit & Stage 2B & $14(2)$ & $3.7(4.2)$ & $0.1(0.3)$ & $0.1(0.8)$ & $56(367)$ & As & $\mathrm{Cu}, \mathrm{Pb}$ \\
\hline Sphalerite & V2 pit & Stage $2 \mathrm{~A}$ & $5(1)$ & 77 (143) & 677 (1181) & 469 (571) & $10(21)$ & $\mathrm{Cu}, \mathrm{Cd}, \mathrm{Pb}$ & $\mathrm{As}, \mathrm{Se}, \mathrm{Ag}, \mathrm{Sb}, \mathrm{Te}$ \\
\hline Sphalerite & V2 pit & Stage $2 \mathrm{~B}$ & $44(4)$ & $206(611)$ & $444(2829)$ & $369(2169)$ & $13(75)$ & $\mathrm{Cu}, \mathrm{Cd}, \mathrm{Pb}$ & $\mathrm{As}, \mathrm{Ag}, \mathrm{Sb}, \mathrm{Hg}$ \\
\hline Sphalerite & A39 pit & Stage $2 B$ & $10(1)$ & $5.1(8.5)$ & $260(476)$ & $20(40)$ & $0.5(2.1)$ & $\mathrm{Cd}, \mathrm{Pb}$ & $\mathrm{Fe}, \mathrm{Cu}, \mathrm{As}, \mathrm{Sb}$ \\
\hline Galena & V2 pit & Stage $2 B$ & $10(1)$ & $0.6(0.9)$ & $0.0(0.1)$ & $2.4(12)$ & $1.1(2.1)$ & $\mathrm{Cu}, \mathrm{Sb}$ & $\mathrm{Zn}, \mathrm{Cd}$ \\
\hline Galena & A39 pit & Stage 2B & $7(1)$ & $0.5(0.8)$ & $\mathrm{bd}$ & $0.7(1.2)$ & $0.4(0.9)$ & $\mathrm{Ag}, \mathrm{Sb}$ & - \\
\hline Dickite & V2 pit & Stage 3 & $10(1)$ & $3.1(4.1)$ & $100(109)$ & $0.1(0.5)$ & $0.0(0.0)$ & $\mathrm{P}, \mathrm{Sr}$ & $\mathrm{Ca}, \mathrm{Fe}, \mathrm{Ba}, \mathrm{Pb}$ \\
\hline Dickite & A39 pit & Stage 3 & $30(3)$ & $5.2(9.1)$ & $86(150)$ & $0.0(0.2)$ & $0.0(0.0)$ & - & - \\
\hline \multicolumn{10}{|c|}{ Samples from other high-sulfidation epithermal and porphyry deposits } \\
\hline Enargite & Lepanto & Eng, Py, Luz, Tn-Td, Cv & $15(1)$ & $38(57)$ & $0.2(1.3)$ & $3.7(8.0)$ & $1.3(7.6)$ & $\mathrm{Sb}, \mathrm{Te}$ & $\mathrm{Fe}, \mathrm{Se}, \mathrm{Sn}$ \\
\hline Enargite & Laurani & Eng, Py, Luz, Tn-Td & $15(1)$ & $12(15)$ & $0.0(0.3)$ & $9.1(17)$ & $0.2(1.4)$ & $\mathrm{Sb}, \mathrm{Sn}$ & $\mathrm{Zn}, \mathrm{Cd}, \mathrm{Te}, \mathrm{Hg}$ \\
\hline Enargite & La Mejicana & Eng, Py, Luz & $16(1)$ & $717(2679)$ & $4.2(15)$ & $5.2(18)$ & $1.4(10)$ & $\mathrm{Sb}$ & $\mathrm{Fe}, \mathrm{Zn}, \mathrm{Sn}, \mathrm{Bi}$ \\
\hline Enargite & Motomboto & Eng, Py & $15(1)$ & $21(50)$ & $0.4(3.3)$ & $1.3(1.8)$ & $0.2(0.8)$ & $\mathrm{Sb}, \mathrm{Bi}$ & $\mathrm{Fe}, \mathrm{Se}$ \\
\hline Enargite & Chelopech & Eng, Py, Luz, Cp, Tn-Td & $15(1)$ & $101(186)$ & $0.2(0.6)$ & $1.1(1.3)$ & $0.1(0.4)$ & $\mathrm{Sb}$ & $\mathrm{Fe}, \mathrm{Bi}$ \\
\hline Enargite & Cerro Quema & Eng, Py, Luz, Cp, Cv & $10(1)$ & $562(1202)$ & $0.1(0.6)$ & $1.4(2.0)$ & $0.0(0.3)$ & $\mathrm{Sb}, \mathrm{Fe}$ & $\mathrm{Hg}$ \\
\hline Enargite & El Salvador & Eng, Py, Tn-Td, Cp & $5(1)$ & $12(24)$ & $0.0(0.1)$ & $1.3(1.6)$ & $15(72)$ & $\mathrm{Sb}$ & $\mathrm{Sn}, \mathrm{Te}$ \\
\hline
\end{tabular}




\subsection{Argyrodite}

Argyrodite [orthorombic $\mathrm{Ag}_{8} \mathrm{GeS}_{6}$ ], the mineral from which Ge was first detected [61], occurs in the Stage $2 \mathrm{~A}$ ores as up to $\sim 100 \mu \mathrm{m}$ big, anhedral crystals intergrown with barite and enargite (Figure 5C). The presence of argyrodite appears to be restricted to the distal, Ag-rich parts of the deposit (A39 pit). The analysed compositional range of $\mathrm{Mt}$ Carlton argyrodite is $\left(\mathrm{Ag}_{7.03-7.80} \mathrm{Cu}_{0.11-0.67} \mathrm{~Pb}_{0.00-0.01}\right)$ $\left(\mathrm{Ge}_{0.86-1.06} \mathrm{As}_{0.00-0.08} \mathrm{Sb}_{0.00-0.05} \mathrm{Bi}_{0.00-0.01}\right)\left(\mathrm{S}_{4.36-5.62} \mathrm{Se}_{0.61-1.44} \mathrm{Te}_{0.03-0.46}\right)$, based on 23 spot analyses on two different grains from separate samples (Table 4, Supplementary Table S2). One grain showed a composition close to argyrodite sensu stricto, while the other grain corresponds to a Se-rich analogue of argyrodite [ideally $\mathrm{Ag}_{8} \mathrm{GeSe}_{2} \mathrm{~S}_{4}$ ] (Figure 6). The presence of $\mathrm{Cu}$ in argyrodite suggests minor solid solution towards putzite $\left[\mathrm{Cu}_{4.7} \mathrm{Ag}_{3.3} \mathrm{GeS}_{6}\right.$ ] [62]. The mineral also locally contains minor amounts of $\mathrm{As}, \mathrm{Sb}$ and $\mathrm{Bi}$, presumably substituting for $\mathrm{Ge}$. The average $\mathrm{Ge}$ concentration in argyrodite is $5.76 \mathrm{wt} \%$ (up to $6.95 \mathrm{wt} \%$ ) (Table 4, Supplementary Table S2).

Table 4. Electron microprobe composition of argyrodite from Mt Carlton.

\begin{tabular}{ccccccccccccc}
\hline $\mathbf{n}=\mathbf{2 3}$ & $\mathbf{S e}$ & $\mathbf{G e}$ & $\mathbf{A g}$ & $\mathbf{T e}$ & $\mathbf{S}$ & $\mathbf{A s}$ & $\mathbf{C u}$ & $\mathbf{A u}$ & $\mathbf{S b}$ & $\mathbf{B i}$ & $\mathbf{P b}$ & Total \\
\hline Mean (wt \%) & 8.06 & 5.76 & 69.65 & 3.26 & 12.84 & 0.22 & 1.26 & 0.01 & 0.05 & 0.10 & 0.03 & 101.25 \\
Minimum & 4.34 & 5.19 & 68.56 & 0.38 & 11.66 & 0.03 & 0.59 & 0.00 & 0.00 & 0.00 & 0.00 & 99.94 \\
Maximum & 9.52 & 6.95 & 71.47 & 4.90 & 16.32 & 0.50 & 3.78 & 0.03 & 0.57 & 0.26 & 0.14 & 101.77 \\
\hline Mean (apfu) & 1.21 & 0.93 & 7.59 & 0.30 & 4.69 & 0.03 & 0.23 & 0.00 & 0.00 & 0.01 & 0.00 & \\
Minimum & 0.61 & 0.86 & 7.03 & 0.03 & 4.36 & 0.00 & 0.11 & 0.00 & 0.00 & 0.00 & 0.00 & \\
Maximum & 1.44 & 1.06 & 7.80 & 0.46 & 5.62 & 0.08 & 0.67 & 0.00 & 0.05 & 0.01 & 0.01 & \\
\hline
\end{tabular}

Mineral formulae calculated based on 15 total atoms.

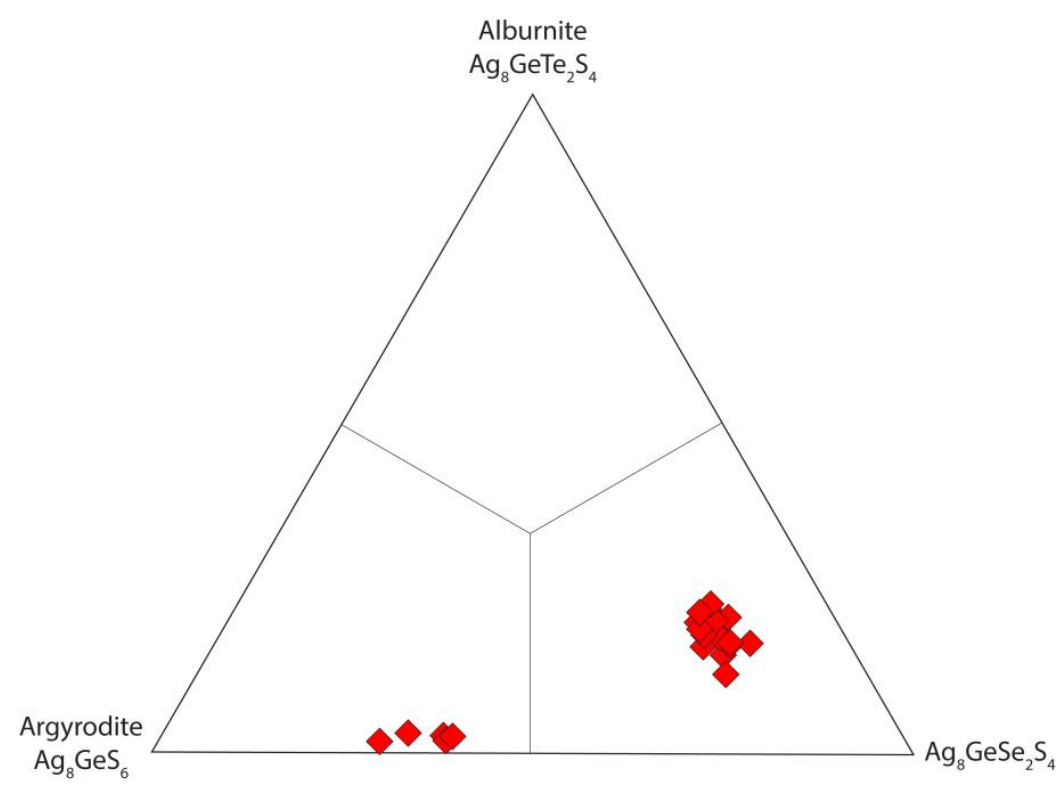

Figure 6. Compositional plot of argyrodite from Mt Carlton, based on WDS spot data (in apfu). The two clusters represent analyses of two individual grains.

\subsection{Enargite}

Enargite [orthorhombic $\mathrm{Cu}_{3} \mathrm{AsS}_{4}$ ] is the principal mineral in the Stage 2A ores at Mt Carlton. Enargite occurs as masses of anhedral to subhedral crystals that host most of the subordinate minerals (Figures 4C and 5D). Trace element data was obtained for enargite from the V2 pit ( $\mathrm{n}=14,2$ samples) and the A39 pit ( $\mathrm{n}=20,2$ samples) (Table 3, Supplementary Table S3). Mt Carlton enargite shows moderate to high enrichment in Ge, with average concentrations of $86 \mathrm{ppm}$ in V2 samples (up to 
$330 \mathrm{ppm}$ ) and $612 \mathrm{ppm}$ in A39 samples (up to $2189 \mathrm{ppm}$ ). Both In (average $14 \mathrm{ppm}$ in V2, $7.7 \mathrm{ppm}$ in A39) and Ga (average $6.0 \mathrm{ppm}$ in V2, $5.2 \mathrm{ppm}$ in A39) are generally low, but significant concentrations are present locally (e.g., up to $155 \mathrm{ppm}$ In and $37 \mathrm{ppm}$ Ga in V2).

Comparing trace elements with average concentrations above $100 \mathrm{ppm}$ in Mt Carlton enargites, the V2 samples are relatively enriched in Sb, Bi and Sn (Supplementary Table S3). Both Bi and Sn are elements indicative of higher temperature conditions [63] and both are commonly present in HS deposits (e.g., Pierina in Peru and Rodalquilar in Spain; [20]). Samples from A39 are in turn relatively enriched in $\mathrm{Zn}, \mathrm{Ag}$, $\mathrm{Ge}$ and $\mathrm{Pb}$. The concentrations of Te, Se and Fe are similar in samples from V2 and A39. Gold has average concentrations of $12 \mathrm{ppm}$ in V2 (up to $62 \mathrm{ppm}$ ) and $0.2 \mathrm{ppm}$ in A39 (up to 1.4 ppm) (Supplementary Table S3). Previous studies of the Far Southeast-Lepanto porphyry-epithermal system (Mankayan, Philippines) have revealed a spatial variability in the trace element composition of enargite [64,65]. Enargite collected close to the Far Southeast porphyry deposit was enriched in Au-Te, enargite collected from the center of the Lepanto HS deposit was enriched in $\mathrm{Ag}-\mathrm{Fe}-\mathrm{Pb}$, and enargite collected from the most distal ores was enriched in $\mathrm{Zn}( \pm \mathrm{Cd})$ [65]. From proximal to distal, the Sn content in enargite was progressively decreasing [64]. The trace element signatures for enargite from Mt Carlton in part corroborate the trends observed at Far Southeast-Lepanto, suggesting that this method may have some potential as a vectoring tool for exploration in the porphyry-epithermal environment. Furthermore, at the Rodalquilar HS deposit, the presence of anomalous Sn concentrations (high enough to form Sn-bearing minerals such as cassiterite (wood tin), colusite or rodalquilarite; [66]) was considered to be a prospective guide to high Au grade mineralized structures [67].

\subsection{Barite}

Barite [orthorhombic $\mathrm{BaSO}_{4}$ ] is present in Stage 2A ores as up to $\sim 0.5 \mathrm{~cm}$ large anhedral to subhedral crystals intergrown with the enargite assemblage (Figure 5C). More rarely it occurs as halos to enargite veinlets (Figure 4F). Barite is most abundant in the distal and shallow parts of the Mt Carlton deposit (A39 pit) [30]. The LA-ICP-MS analyses of barite from the A39 pit ( $\mathrm{n}=53,4$ samples) yielded concentrations of Ge, Ga and In consistently below 2 ppm (Table 3, Supplementary Table S1). Barite has high concentrations of $\mathrm{Pb}$ (average $1.3 \mathrm{wt} \%$ ) and $\mathrm{Sr}$ (average $2406 \mathrm{ppm}$ ). This reflects significant solid solution toward hokutolite $\left[(\mathrm{Ba}, \mathrm{Pb}, \mathrm{Sr}) \mathrm{SO}_{4}\right]$, a plumbian variety of barite reported from some acidic hot springs (e.g., the Tamagawa Hot Spring in Japan and the Peitou Hot Spring in Taiwan). The identification of $\mathrm{Pb}$-rich barite at $\mathrm{Mt}$ Carlton has some significance for exploration, as this mineral potentially is responsible for the distal $\mathrm{Pb}$ geochemical anomaly observed at the deposit [30]. Other elements enriched in barite include Ca (average 333 ppm), La (average 202 ppm) and Ce (average 155 ppm), and to a lesser degree Al, P, Ti, Cu and Zn (all average 10-100 ppm) (Table 3, Supplementary Table S1).

\subsection{Pyrite}

Pyrite [isometric $\mathrm{FeS}_{2}$ ] is present in Stage $2 \mathrm{~A}$ ores as up to $\sim 1 \mathrm{~cm}$ large subhedral crystals intergrown mainly with massive enargite and luzonite (Figure $4 C$ ). Stage $2 B$ in turn contains up to $\sim 0.5 \mathrm{~cm}$ large subhedral pyrite crystals mainly intergrown with sphalerite and galena (Figure $5 \mathrm{E}$ ). Pyrite grains from Stage 2A ( $\mathrm{n}=14,2$ samples) and Stage $2 B(\mathrm{n}=14,2$ samples) consistently show low concentrations of Ge, Ga and In (below 5 ppm; Table 3, Supplementary Table S3). Both stages of pyrite exhibit similar enrichment in $\mathrm{Cu}$ (average $>700 \mathrm{ppm}$; Supplementary Table S3). Stage 2A pyrite shows a relative enrichment in $\mathrm{Co}, \mathrm{Ni}, \mathrm{Zn}$ and $\mathrm{Ag}$ (average 100-500 ppm), while Stage 2B pyrite is richer in As (average $2443 \mathrm{ppm}$, up to $1.2 \mathrm{wt} \%$ ) and $\mathrm{Pb}$ (average $314 \mathrm{ppm}$ ). The high As concentrations in Stage $2 \mathrm{~B}$ pyrite could be related to the low abundance of independent As minerals (e.g., tennantite) in this mineral assemblage. Furthermore, Stage 2B pyrite is significantly enriched in Au (average $56 \mathrm{ppm}$ and up to $367 \mathrm{ppm}$ ) relative to Stage 2A pyrite (average $2.4 \mathrm{ppm}$ and up to $11 \mathrm{ppm}$ ). This is consistent with previously made observations of high incorporation of Au in arsenian pyrite [68]. 


\subsection{Sphalerite}

Sphalerite [isometric $\mathrm{ZnS}$ ] is present in small quantities in the Stage 2A ores. It occurs intergrown with enargite and luzonite as up to $\sim 150 \mu \mathrm{m}$ large, subhedral crystals that exhibit a dark brown to black color (Figure 5D). Sphalerite is the principal mineral in the Stage 2B ores, where it has a massive to colloform texture, with colors varying from almost transparent to dark brown (Figures $4 \mathrm{D}$ and $5 \mathrm{E}, \mathrm{F}$ ).

Trace element data was obtained for Stage 2A sphalerite from V2 ( $n=5,1$ sample) and Stage 2B sphalerite from V2 ( $\mathrm{n}=44,4$ samples) and A39 ( $\mathrm{n}=10,1$ sample). Stage 2A sphalerite shows average concentrations of $77 \mathrm{ppm}$ Ge (up to $143 \mathrm{ppm}$ ), $677 \mathrm{ppm} \mathrm{Ga} \mathrm{(up} \mathrm{to} 1181 \mathrm{ppm}$ ) and $469 \mathrm{ppm}$ In (up to $571 \mathrm{ppm}$ ) (Table 3, Supplementary Table S3). Stage 2B sphalerite from V2 yielded average concentrations of $206 \mathrm{ppm} \mathrm{Ge} \mathrm{(up} \mathrm{to} 611 \mathrm{ppm}$ ), $444 \mathrm{ppm} \mathrm{Ga} \mathrm{(up} \mathrm{to} 2829 \mathrm{ppm}$ ) and $369 \mathrm{ppm}$ In (up to $2169 \mathrm{ppm}$ ). Stage 2B sphalerite from A39 in turn shows significantly lower average concentrations of these elements, including $5.1 \mathrm{ppm} \mathrm{Ge} \mathrm{(up} \mathrm{to} 8.5 \mathrm{ppm}$ ), $260 \mathrm{ppm} \mathrm{Ga} \mathrm{(up} \mathrm{to} 476 \mathrm{ppm}$ ) and $20 \mathrm{ppm}$ In (up to $40 \mathrm{ppm}$ ).

Both Stage 2A and Stage 2B sphalerite are highly enriched in $\mathrm{Cu}, \mathrm{Cd}$ and $\mathrm{Pb}$ (average $>1000 \mathrm{ppm}$ ) (Table 3, Supplementary Table S3). The Cu content in Stage 2B sphalerite decreases from proximal (average $2013 \mathrm{ppm} \mathrm{Cu}$ in V2) to distal (average $486 \mathrm{ppm} \mathrm{Cu}$ in A39), which is consistent with the deposit scale metal zonation (Figure 2). Other elements with average concentrations in excess of $100 \mathrm{ppm}$ in sphalerite include As, Ag and Sb (both stages), Se and Te (Stage 2A), and Fe and $\mathrm{Hg}$ (Stage 2B). Concentrations of $\mathrm{Au}$ are locally significant in sphalerite from both stages (up to $21 \mathrm{ppm}$ in Stage 2A and up to 75 ppm in Stage 2B) (Table 3, Supplementary Table S3).

Germanium, Ga and In all show smooth downhole profiles in sphalerite, confirming that they are predominantly hosted in solid solution in this mineral [69]. Substitution of In and Ga into sphalerite can occur via coupled substitution with monovalent cations, and with $\mathrm{Cu}^{+}$in particular $[1,15,16,42,69-73]$. A positive correlation was observed in the $\mathrm{Cu}+\mathrm{Ag}$ vs. In $+\mathrm{Ga}$ plot (Figure 7), corroborating the coupled substitution $2 \mathrm{Zn}^{2+} \leftrightarrow(\mathrm{Cu}, \mathrm{Ag})^{+}+(\mathrm{In}, \mathrm{Ga})^{3+}$. In general there is an excess of $\mathrm{Cu}$ over $\mathrm{Ag}$ in sphalerite, suggesting that $\mathrm{Cu}$ is the principal cation involved in the substitution. No statistically significant correlation was observed between Ge and other trace elements in sphalerite, something that has also been noted in previous studies $[69,74,75]$. This could potentially suggest that Ge substituted for $\mathrm{Zn}$ with vacancies in the structure to allow for charge balance, i.e., $2 \mathrm{Zn}^{2+} \leftrightarrow \mathrm{Ge}^{4+}+\square[74,75]$.

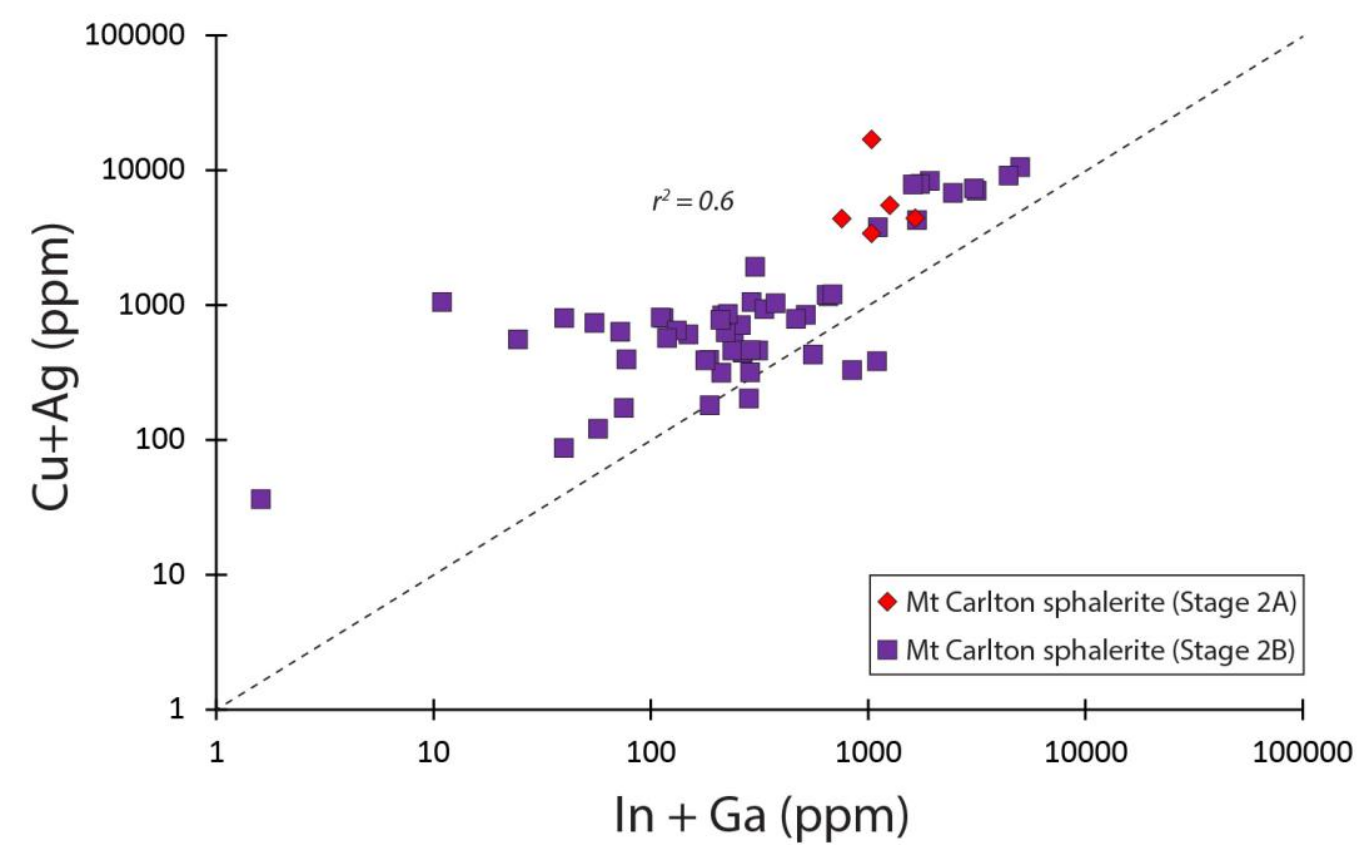

Figure 7. Correlation plot of $\mathrm{Cu}+\mathrm{Ag}$ vs. In + Ga in Mt Carlton sphalerite, based on LA-ICP-MS spot data. 


\subsection{Galena}

Galena [isometric $\mathrm{PbS}$ ] in Stage $2 \mathrm{~B}$ occurs as up to $\sim 0.5 \mathrm{~cm}$ large, euhedral to subhedral crystals intergrown mainly with sphalerite and pyrite (Figure $5 \mathrm{E}$ ). This galena contains abundant segregations of tennantite (Figure 5E). Trace element data for Stage 2B galena from V2 $(n=10,1$ sample) and A39 $(\mathrm{n}=7,1$ sample) reveals concentrations of $\mathrm{Ge}, \mathrm{Ga}$ and In that are consistently below 5 ppm (Table 3, Supplementary Table S3). Elements with average concentrations in excess of $100 \mathrm{ppm}$ include Sb, Ag, $\mathrm{Cu}, \mathrm{Zn}$ and $\mathrm{Cd}$, which are all common trace components in galena [76]. The Ag content in galena is particularly high in samples from the A39 pit (average $1443 \mathrm{ppm}$, up to $3447 \mathrm{ppm}$ ). No independent Ag minerals have been identified in the Stage $2 \mathrm{~B}$ assemblage, however, whole rock analyses of these ores have showed significant Ag grades (up to 2143 ppm Ag in samples from A39; [30]). The abundance of galena combined with the high Ag content in the mineral, therefore, suggest it is an important $\mathrm{Ag}$ carrier in the Stage 2B ores.

\subsection{Dickite}

Dickite [monoclinic $\mathrm{Al}_{2} \mathrm{Si}_{2} \mathrm{O}_{5}(\mathrm{OH})_{4}$ ] within the Stage 3 void fill is generally massive, microcrystalline and exhibits a translucent to whitish or bluish color (Figure $4 \mathrm{~F}$ ). Trace element data was obtained for dickite from the V2 pit ( $\mathrm{n}=10,1$ sample) and the A39 pit ( $\mathrm{n}=30,3$ samples). Dickite exhibits moderate to locally high enrichment in $\mathrm{Ga}$, with average concentrations of $100 \mathrm{ppm}$ (up to $109 \mathrm{ppm}$ ) in V2 samples and $86 \mathrm{ppm}$ (up to $150 \mathrm{ppm}$ ) in A39 samples (Table 3, Supplementary Table S1). Smooth downhole signals were observed for Ga in dickite, and the signals closely matched those of $\mathrm{Al}$, again suggesting direct substitution of $\mathrm{Ga}^{3+}$ for $\mathrm{Al}^{3+}$. Germanium and In were always below $10 \mathrm{ppm}$ and $1 \mathrm{ppm}$, respectively. Other trace elements present in significant concentrations in $\mathrm{Mt}$ Carlton dickite include $\mathrm{P}, \mathrm{Ca}, \mathrm{Fe}, \mathrm{Sr}, \mathrm{Ba}$ and $\mathrm{Pb}$, and the $\mathrm{V} 2$ sample showed distinctly higher concentrations of these elements relative to the A39 samples (Table 3, Supplementary Table S1).

\section{Composition of Enargite from Reference Deposits}

Reference samples of enargite were analyzed from Lepanto $(n=15)$, Laurani $(n=15)$, La Mejicana $(n=16)$, Motomboto $(n=15)$, Chelopech $(n=15)$, Cerro Quema $(n=10)$ and El Salvador $(n=5)$ (Table 2). Only one polished section lacking detailed spatial information was analyzed from each locality. Given that a spatial variability can be expected for many trace elements in enargite $([64,65]$; this study), these samples are not necessarily representative for the entire deposit from which they are derived. Nevertheless, the samples provide valuable information on the trace element content of enargite from HS deposits, which can be compared with the results from Mt Carlton.

Similar to enargite from Mt Carlton, moderate to high Ge concentrations were observed in all of the reference samples. This includes average Ge concentrations of $717 \mathrm{ppm}$ for La Mejicana (up to $2679 \mathrm{ppm}$ ), $562 \mathrm{ppm}$ for Cerro Quema (up to $1202 \mathrm{ppm}$ ), $101 \mathrm{ppm}$ for Chelopech (up to $186 \mathrm{ppm}$ ), $38 \mathrm{ppm}$ for Lepanto (up to $57 \mathrm{ppm}$ ), $21 \mathrm{ppm}$ for Motomboto (up to $50 \mathrm{ppm}$ ), $12 \mathrm{ppm}$ for El Salvador (up to $24 \mathrm{ppm}$ ) and $12 \mathrm{ppm}$ for Laurani (up to $15 \mathrm{ppm}$ ) (Table 3, Supplementary Table S4). Downhole profiles of Ge in enargite (also including Mt Carlton samples) were smooth to undulating. This indicates that Ge occurs in solid solution, with a locally zoned distribution, something that is also visible in WDS element maps (Figure 8). Germanium shows a broad correlation with Zn in both WDS element maps (Figure 8) and in LA-ICP-MS spot data (Figure 9). Assuming that $\mathrm{Cu}$ is monovalent and As is pentavalent in the enargite lattice [77], this might suggest that Ge is in part incorporated via the coupled substitution $\mathrm{As}^{5+}+\mathrm{Cu}^{+} \leftrightarrow \mathrm{Ge}^{4+}+\mathrm{Zn}^{2+}$, as proposed by Bernstein (1985) [9]. Specifically, enargite from La Mejicana exhibits a strong correlation between Ge and Zn (Figures 8B and 9); however, the absolute concentrations of $\mathrm{Zn}$ are consistently lower than those of Ge (Figure 9). This suggests that additional substitution mechanisms must also be involved in the incorporation of Ge into enargite. 


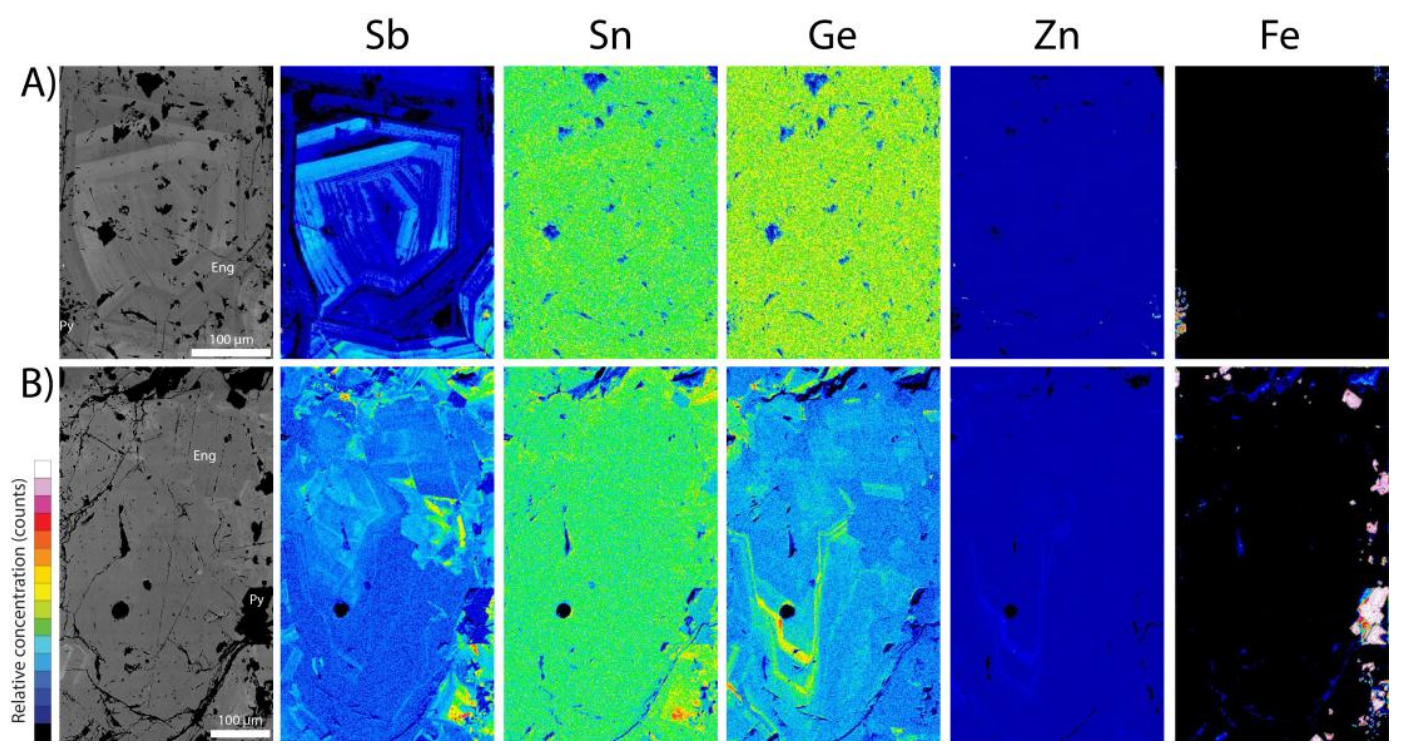

Figure 8. BSE images (left) and X-ray intensity maps of selected elements in enargite. (A) Enargite crystal from Mt Carlton showing an oscillatory zoning primarily related to Sb content. Zinc and Ge are homogenously distributed in the crystal, while Sn shows a faint enrichment in Sb-rich zones. (B) Zoned enargite crystal from La Mejicana. Growth zones enriched in Ge are also enriched in Zn. A relatively homogenous distribution is observed for Sn, but locally it shows high enrichments in areas also marked by a high Sb content. Mineral abbreviations: Eng—enargite; Py—pyrite.

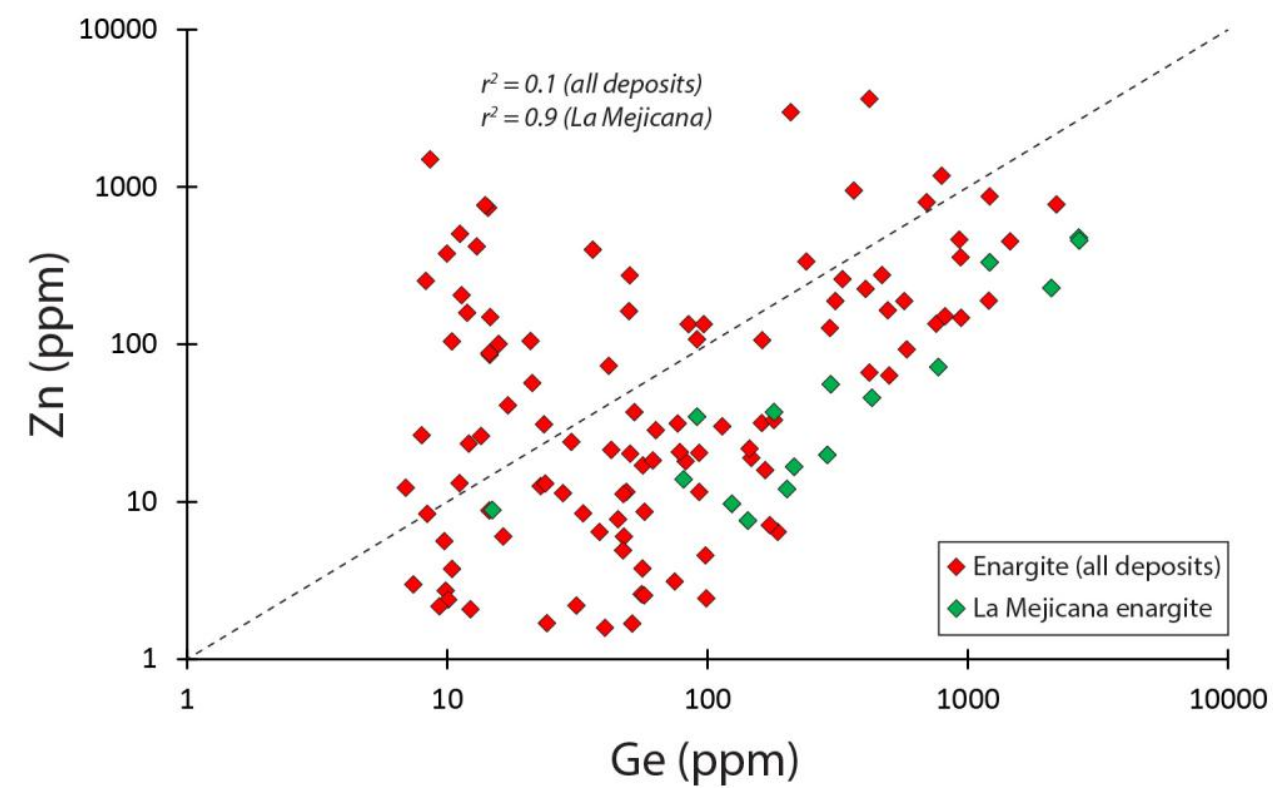

Figure 9. Correlation plot of $\mathrm{Zn}$ vs. Ge in enargite from all deposits included in this study (red diamonds), based on LA-ICP-MS spot data. Enargite from La Mejicana (highlighted in green) show a particularly strong correlation between $\mathrm{Zn}$ and $\mathrm{Ge}$, however, the concentrations of $\mathrm{Zn}$ are consistently lower than those of $\mathrm{Ge}$ (below the 1:1 correlation line).

Both Ga and In are generally low in the reference enargite samples, however, moderate concentrations were observed locally in the samples from La Mejicana (up to $15 \mathrm{ppm}$ Ga and 18 ppm In) and Laurani (up to 17 ppm In) (Table 3, Supplementary Table S4). Other trace elements with average concentrations in excess of $100 \mathrm{ppm}$ in the reference enargite samples include $\mathrm{Sb}$ (all deposits), Fe (Cerro Quema, Motomboto, Chelopech, La Mejicana, Lepanto), Zn (La Mejicana, 
Laurani), Se (Lepanto, Motomboto), Cd (Laurani), Sn (Laurani, Lepanto, La Mejicana, El Salvador), Te (El Salvador, Lepanto, Laurani), Hg (Laurani, Cerro Quema) and Bi (Motomboto, Chelopech, La Mejicana) (Table 3, Supplementary Table S4). The Au content in these enargites varied from below detection limit to tens of ppm (up to $72 \mathrm{ppm}$ at El Salvador), confirming that enargite can be a significant Au carrier in HS and porphyry deposits [65].

\section{Discussion}

The results of the present study, combined with available evidence from case studies in the literature, suggest that there are three distinct mineral associations in HS deposits that may host critical element enrichment. These include: (1) Ga enrichment in Al-bearing hydrothermal sulfates and silicates, (2) Ge \pm In-Ga enrichment in high-sulfidation enargite ores, and (3) In-Ga \pm Ge enrichment in intermediate-sulfidation sphalerite ores.

\subsection{Ga Enrichment in Al-Bearing Sulfates and Silicates}

This study highlights how Ga may be present in moderate to high concentrations in Al-bearing hydrothermal sulfates and silicates such as alunite and dickite, due to substitution of $\mathrm{Ga}^{3+}$ into the structural sites normally occupied by $\mathrm{Al}^{3+}$ in these minerals. Equivalent substitutions $\left(\mathrm{Ga}^{3+} \leftrightarrow \mathrm{Fe}^{3+}\right)$ should be possible in $\mathrm{Fe}^{3+}$-analogues to such minerals. Exceptionally high $\mathrm{Ga}$ contents in minerals of the alunite supergroup have previously been documented in the oxidized zones of Tsumeb-type polymetallic deposits. The Tsumeb deposit in Namibia locally contains supergene gallobeudantite $\left[\mathrm{PbGa}_{3}\left(\mathrm{AsO}_{4}\right)\left(\mathrm{SO}_{4}\right)(\mathrm{OH})_{6}\right]$ [58] and galloplumbogummite $\left[\mathrm{Pb}(\mathrm{Ga}, \mathrm{Al})_{3}\left(\mathrm{PO}_{4}\right)_{2}(\mathrm{OH})_{6}\right]$ [78], while similar ores at the Apex Mine in Utah contain supergene jarosite [the $\mathrm{Fe}^{3+}$-analogue to alunite; $\left.\mathrm{KFe}_{3}\left(\mathrm{SO}_{4}\right)_{2}(\mathrm{OH})_{6}\right]$ with up to 7000 ppm Ga $[79,80]$. At the Apex Mine, the world's only deposit ever considered as a primary Ga and Ge producer, jarosite is one of the principal Ga carriers $[79,80]$.

Compared to the above examples, the Ga concentrations in alunite and dickite at Mt Carlton are distinctly lower. However, they are comparable to those of worldwide bauxite deposits (average 57 ppm Ga; [81]), the main source of the global Ga supply [14]. Similar Ga enrichment to that at Mt Carlton has previously been documented in whole rock samples from the advanced argillic alteration zone at the Paradise Peak HS deposit in Nevada (up to 120 ppm Ga; [82]). The similarities between X-ray absorption spectra of these samples and those of gallium sulfate suggest that the $\mathrm{Ga}$ there is predominantly hosted in alunite [82]. Alunite is a primary ore mineral for $\mathrm{Al}, \mathrm{K}$ and $\mathrm{S}$ in exceptionally alunite-rich HS deposits similar to those at Alunite Ridge in Utah [83] and Red Mountain in Colorado [84], several of which have been exploited historically. The added possibility of recovering $\mathrm{Ga}$ as a by-product could spark a renewed interest in such occurrences. Furthermore, there could be potential for recovery of Ga from alunite present in the gangue in HS deposits that are primarily mined for their precious and/or base metal contents. Methods for extracting Ga from alunite concentrate have been developed in Japan (e.g., [85]), and more recently in China (e.g., [86]).

\subsection{Ge \pm In-Ga Mineralization in High-Sulfidation Enargite Ores}

The mineralogical distribution of Ge in hydrothermal ores is dependent on the activities of sulfur and oxygen. In relatively reduced fluids with a high sulfur activity, Ge preferentially forms thiogermanate minerals and substitutes into sulfosalts rather than sphalerite (Figure 10; [7,9]). This style of Ge mineralization is best known from Tsumeb-type deposits $[7,9,87,88]$, however, it appears to be common also in HS deposits.

The presence of argyrodite at Mt Carlton is not unique for HS deposits, and a variety of independent Ge sulfide minerals have previously been documented in HS deposits elsewhere. Deposits from the Cretaceous Panagyurishte district of Bulgaria (including the Chelopech, Radka, Krassen and Elshitsa HS deposits) locally contain germanite $\left[\mathrm{Cu}_{13} \mathrm{Fe}_{2} \mathrm{Ge}_{2} \mathrm{~S}_{16}\right]$, renierite $\left[(\mathrm{Cu}, \mathrm{Zn})_{11} \mathrm{Fe}_{4}(\mathrm{Ge}, \mathrm{As})_{2} \mathrm{~S}_{16}\right]$, germanocolusite $\left[\mathrm{Cu}_{13} \mathrm{~V}(\mathrm{Ge}, \mathrm{As})_{3} \mathrm{~S}_{16}\right]$, briartite $\left[\mathrm{Cu}_{2}(\mathrm{Zn}, \mathrm{Fe}) \mathrm{GeS}_{4}\right]$ and Ge-bearing arsenosulvanite $\left[\mathrm{Cu}_{3}(\mathrm{As}, \mathrm{V}, \mathrm{Ge}) \mathrm{S}_{4}\right]$ [89-94]. Neogene epithermal mineralization in the South Apuseni Mountains 
in Romania (including the Bucium, Bucureşci-Rovina, Băița Crăciuneşti and Pârâul lui Avram occurrences) contain argyrodite and/or germanite associated with enargite ([95], and references therein). The Capillitas deposit (Catamarca province, Argentina) comprises a number of mainly intermediate-sulfidation epithermal veins, some of which show high-sulfidation affinities [96]. Oxidized enargite-bearing ores in the mine dumps from the La Rosario vein exhibit a supergene mineral assemblage that contains several original species of Ge sulfides, including putzite $\left[\mathrm{Cu}_{4.7} \mathrm{Ag}_{3.3} \mathrm{GeS}_{6}\right]$, catamarcaite $\left[\mathrm{Cu}_{6} \mathrm{GeWS}_{8}\right]$ and omariniite $\left[\mathrm{Cu}_{8} \mathrm{Fe}_{2} \mathrm{ZnGe}_{2} \mathrm{~S}_{12}\right]$, with zincobriartite also being present in trace amounts [62,96-100].

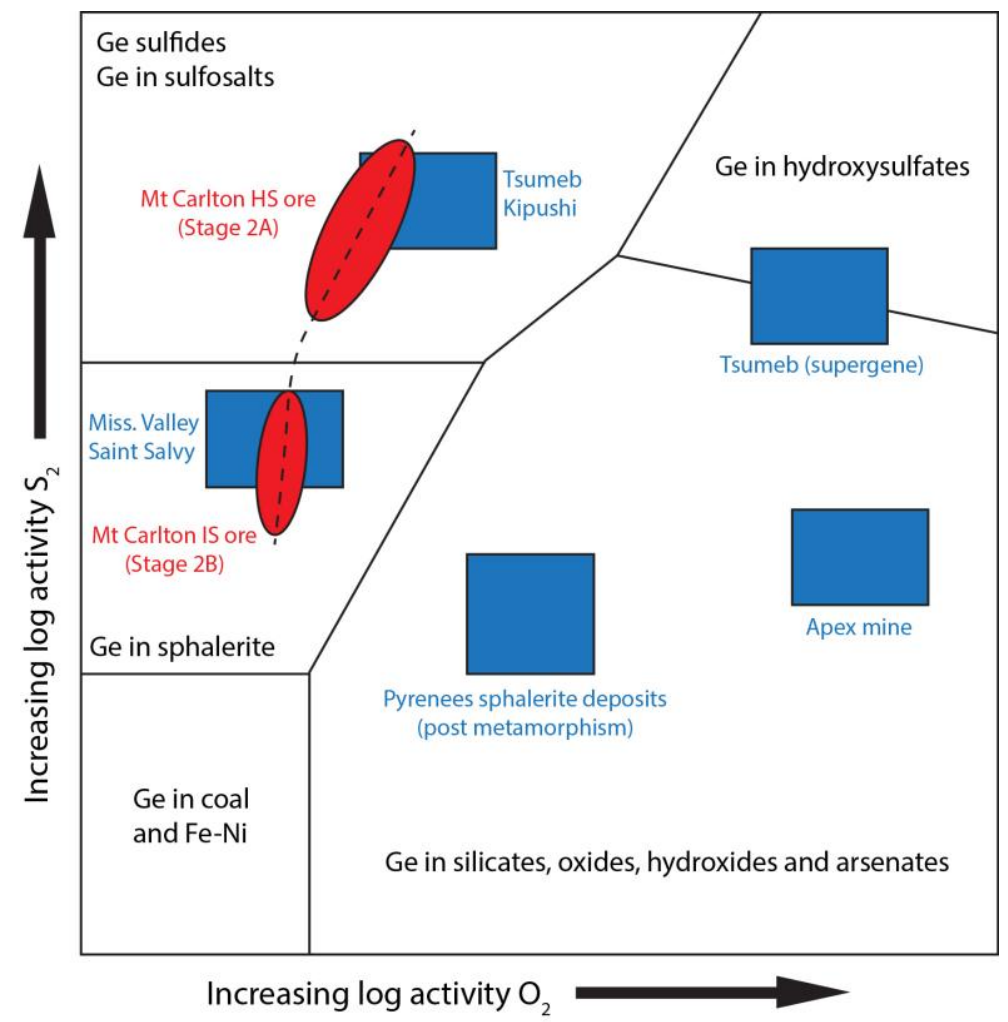

Figure 10. Schematic illustration of Ge behavior in different geologic environments, as a function of the activities of $\mathrm{S}_{2}$ and $\mathrm{O}_{2}$. The Ge mineralization in high-sulfidation (Stage 2A) and intermediate-sulfidation (Stage 2B) epithermal ores at Mt Carlton are compared to various world-class Ge deposits. Modified from Bernstein [9].

Sulfosalts such as enargite, luzonite and tennantite-tetrahedrite are known to incorporate significant concentrations of Ge in Tsumeb-type deposits (up to $~ 5000 \mathrm{ppm} ;[7,9,87,88]$ ). On the basis of LA-ICP-MS analyses of enargite from seven HS deposits and one porphyry deposit conducted in this study, moderate Ge concentrations (10-100 ppm) seem to be common in enargite in these systems. Higher Ge concentrations in enargite (e.g., 100-3000 ppm) are potentially restricted to a smaller number of deposits (e.g., Mt Carlton, La Mejicana, Cerro Quema and Chelopech). Previously, Maydagán et al. [101] reported up to 41 ppm Ge in enargite from the Altar linked porphyry-HS deposit in Argentina. Dekov et al. [102] studied seafloor chimneys made up almost entirely of luzonite and enargite in the Manus backarc basin (offshore of Papua New Guinea). Enargite from these chimneys, which were interpreted as submarine analogues of terrestrial HS deposits, was found to contain up to $137 \mathrm{ppm}$ Ge and $11 \mathrm{ppm} \mathrm{Ga}$, while luzonite contained up to $120 \mathrm{ppm}$ Ge and $106 \mathrm{ppm}$ Ga [102]. Indium was consistently below $1 \mathrm{ppm}$ in both enargite and luzonite. Contrary to the results presented in this study, the highest Ge concentrations in these chimneys were observed in pyrite and marcasite (up to 1287 ppm Ge; [102]). 
Sphalerite is typically a volumetrically minor component of high-sulfidation enargite ores [20]. Based on Figure 10, the Ge concentrations in such sphalerite is expected to be comparatively low (e.g., one order of magnitude lower than those in enargite at Mt Carlton). Sphalerite is probably the preferred host for In and Ga in this assemblage. However, moderate enrichment of these elements may also be present in sulfosalt minerals.

At Mt Carlton, the presence of argyrodite and the high Ge content of enargite are predominantly confined to the distal and shallow, Ag-rich parts of the deposit. This may suggest that mixing of the ore fluid with cooler meteoric waters, and a high activity of Ag, were important controls on this type of Ge mineralization. High-sulfidation enargite ores are generally voluminous in most HS deposits and, thus, represent a potential source of $\mathrm{Ge}$, in addition to their commonly exploited $\mathrm{Au}, \mathrm{Ag}$ and $\mathrm{Cu}$ contents. A potential drawback is the high concentrations of "penalty elements" (e.g., As, $\mathrm{Sb}$ and $\mathrm{Bi}$ ) commonly present in unoxidized ores of this type, which can make them challenging to process economically at lower grades [22,103]. This would probably be less of an issue in oxidized HS deposits, where the ores are significantly easier to process [22]. Indeed, the gossans of some HS deposits (e.g., the La Rosario vein), Tsumeb-type deposits (e.g., Tsumeb and Apex Mine) and polymetallic vein deposits (e.g., San Roque and Pingüino, Argentina; $[104,105])$ are known to be enriched in critical elements, which can be attributed to the general immobility of Ge, Ga and In during weathering $[9,80,105,106]$. In the weathering environment, these elements may form their own exotic minerals, or occur in high concentrations in various supergene minerals (e.g., sulfides, oxides, hydroxides, hydroxy-sulfates and arsenates; $[9,80,98,104])$. From both a mineralogical and economic standpoint it can, therefore, be of interest to further investigate potential mineral hosts of Ge, Ga and In in oxidized HS deposits.

\subsection{In-Ga \pm Ge Mineralization in Intermediate-Sulfidation Sphalerite Ores}

Indium and Ga display a similar distribution in the intermediate-sulfidation sphalerite ores at Mt Carlton. Both elements are primarily hosted in sphalerite and in the "Zn-In mineral". The highest concentrations of In and $\mathrm{Ga}$ in sphalerite occur in the proximal, $\mathrm{Cu}$-rich parts of the deposit. Indeed, a high $\mathrm{Cu}$ activity in the ore fluid is a strong control on In enrichment and, to a lesser degree, Ga enrichment in sphalerite [2], as it allows for extensive incorporation of these elements in coupled substitution with $\mathrm{Cu}$.

Germanium also appears to be hosted predominantly in sphalerite in the Stage 2B ores at Mt Carlton. Indeed, Ge is expected to primarily concentrate into sphalerite at low to moderate sulfur activities (Figure 10; [7,9]). However, a high activity of $\mathrm{Cu}$ or $\mathrm{Ag}$ may still promote the formation of Ge-bearing $\mathrm{Cu}$ or $\mathrm{Ag}$ sulfides at lower sulfur activities [9]. The precise nature of Ge incorporation into sphalerite is less clear, and potentially more complex, than that of In and Ga $[10,69,74,75,107,108]$. It is, therefore, difficult to assess possible physicochemical controls on Ge enrichment in these ores.

In-Ga \pm Ge enrichment in intermediate sulfidation sphalerite ores similar to those at Mt Carlton have been documented elsewhere. The most prominent example is the world-class Toyoha IS deposit in Japan. Toyoha was the world's largest In producer in the 1990s-early 2000s, containing 33,700 kt of ore with an average In grade of $138 \mathrm{ppm}$ [11]. Similar to Mt Carlton, the main carriers of In at Toyoha are In-bearing sphalerite (up to $7 \mathrm{wt} \% \mathrm{In}, 3.6 \mathrm{wt} \% \mathrm{Cu}$ and $273 \mathrm{ppm} \mathrm{Ga} ;[15,69]$ ) and the "Zn-In mineral" [43]. Other In-bearing minerals at Toyoha include roquesite [CuInS ${ }_{2}$ ], stannite-kësterite $\left[\mathrm{Cu}_{2} \mathrm{FeSnS}_{4}-\mathrm{Cu}_{2} \mathrm{ZnSnS}_{4}\right]$, sakuraiite [(Cu,Zn,Fe,In,Sn)S], laforetite [AgInS $\left.{ }_{2}\right]$ and chalcopyrite [43]. The Ge content of Toyoha sphalerite is low (1-4 ppm; [69]). The Agios Philippos HS deposit in Thrace, Greece, contains a stage of $\mathrm{Zn}-\mathrm{Pb}$-rich intermediate-sulfidation ore rich in sphalerite and wurtzite (the hexagonal polymorph of sphalerite). Sphalerite and wurtzite at Agios Philippos exhibit high concentrations of In (up to $3.5 \mathrm{wt} \%$ ), Ga (up to $1.6 \mathrm{wt} \%$ ) and Ge (up to $800 \mathrm{ppm}$ ) [109-111]. The Roşia Montană IS deposit in the South Apuseni Mountains in Romania locally contains alburnite $\left[\mathrm{Ag}_{8} \mathrm{GeTe}_{2} \mathrm{~S}_{4}\right]$, the Te-rich analogue of argyrodite [95,112], as well as sphalerite with up to $73 \mathrm{ppm} \mathrm{Ge}$, 366 ppm Ga, 38 ppm In and 1906 ppm Cu [69]. The Nueva Esperanza HS vein at the Capillitas deposit in Argentina is the type locality of the rare Ga-In mineral ishiharaite $[(\mathrm{Cu}, \mathrm{Ga}, \mathrm{Fe}, \mathrm{In}, \mathrm{Zn}) \mathrm{S}]$. The mineral 
is associated with a late intermediate-sulfidation state assemblage containing In-bearing sphalerite and tennantite, as well as pyrite, chalcopyrite and galena [113]. A final example is the Palai-Islica IS deposit in Spain, where sphalerite is variably enriched in Ge (up to $0.42 \mathrm{wt} \%$ ), Ga (up to $0.16 \mathrm{wt} \%$ ), In (up to $0.43 \mathrm{wt} \%$ ) and $\mathrm{Cu}$ (up to $1.72 \mathrm{wt} \%$ ) [114].

There is, thus, a noteworthy potential for In-Ga \pm Ge enrichment in (Cu-rich) intermediatesulfidation sphalerite ores in the epithermal environment. This mineralization style may be present in both HS deposits (e.g., Mt Carlton, Agios Philippos, Nueva Esperanza vein) and IS deposits (e.g., Toyoha, Roşia Montană and Palai-Islica). When sphalerite in such deposits is volumetrically significant enough to be processed, the possibility of extracting critical elements as by-products could increase the value of these ores (e.g., Toyoha).

\subsection{Petrogenetic Considerations}

Studies of active volcanic fumaroles further highlight the potential for significant transport and enrichment of $\mathrm{Ge}, \mathrm{Ga}$ and In in epithermal settings. Analyses of volcanic gases and precipitates from Merapi Volcano, Indonesia $[115,116]$ and Kudryavy Volcano, Russia $[117,118]$ show significant enrichment factors for these elements $\left(1-10^{2}\right.$ for Ge and $\mathrm{Ga}, 10^{4}-10^{5}$ for $\left.\mathrm{In}\right)$ in the fumarolic discharge products compared to the underlying, degassing magma. For comparison, the hydrothermal system related to the submarine Brothers Volcano (Kermadec Arc, New Zealand) has a strong magmatic contribution, and mineralogical similarities to terrestrial HS deposits have been documented (e.g., enargite, alunite and anhydrite; $[63,119])$. Analyses of precipitates from several seafloor chimneys related to Brothers revealed locally high concentrations of $\mathrm{Ga}$ (up to $1870 \mathrm{ppm}$ ), and to a lesser degree Ge (up to $194 \mathrm{ppm}$ ) and In (up to $144 \mathrm{ppm}$ ) [63]. In most hydrothermal fluids, transport of Ge and Ga is expected to dominantly be in the form of hydroxide complexes. However, fluoride complexes or sulfur-bearing species may also be important in particularly F-rich or S-rich solutions, respectively ([106], and references therein). The behavior of In is expected to be more variable, and hydroxide, chloride, fluoride or bisulfide complexes may all contribute to its transport, depending on conditions ([106], and references therein).

The incompatible elements Ge, Ga and In may be enriched through fractional crystallization, remaining in the residual igneous liquids $[1,7,9,120]$. Due to their chalcophile properties, enrichment of these elements has been linked to sulfur-rich and oxidized magmatism [1,9,11,16,121], typical of a porphyry-epithermal environment [23,122]. Additionally, Ge, Ga and In may be mobilized into magmas and hydrothermal fluids from sedimentary country rocks, in particular those rich in organic matter. Both Ge and Ga form strong bonds with organic compounds in coals and related organic materials, and coal deposits represent a significant resource of Ge and Ga globally $[7,9,13,14]$. As an example, coal seams from the upper Devonian Chattanooga black shale in Tennessee were found to contain up to $760 \mathrm{ppm} \mathrm{Ge}$ (up to $4.5 \mathrm{wt} \%$ Ge and $50 \mathrm{ppm}$ Ga in the coal ash), with the shale itself containing up to $18 \mathrm{ppm} \mathrm{Ge} \mathrm{[123].} \mathrm{Uptake} \mathrm{of} \mathrm{Ge} \mathrm{and} \mathrm{Ga} \mathrm{from} \mathrm{such} \mathrm{carbonaceous}$ sedimentary rocks by migrating hydrothermal fluids has been suggested as an important process for Ge-Ga mineralization in several MVT and Tsumeb-type deposits $[7,9,88]$. Indium also has a slight tendency to be enriched in reduced, carbonaceous sedimentary rocks [124]. In the Japanese island arc, assimilation of basement pelitic rocks is believed to have played an important role in supplying In and reducing agents to the oxidized magmas that formed Toyoha and other In-Sn-bearing polymetallic vein deposits $[11,16,121]$. The HS deposits from which samples showed high enrichment in critical elements in this study (Mt Carlton, La Mejicana, Chelopech, Cerro Quema) are all hosted in stratigraphic sequences that locally contain carbonaceous sedimentary rocks (Table 2, and references therein; [30]). For example, the Panagyurishte district that hosts Chelopech and several other Ge-(Ga-In) enriched HS deposits (Radka, Krassen and Elshitsa) contains an up to $400 \mathrm{~m}$ thick basal sequence of coal-bearing sandstones and conglomerates $[48,94]$. Such rocks seem to be largely lacking or ambiguous in the deposits from which samples showed more moderate critical element enrichment (Lepanto, El Salvador, Motomboto), with Laurani being the exception (Table 2, and references therein). 
In addition to magmatic-hydrothermal processes, carbonaceous sedimentary rocks could potentially be important for the concentration of Ge, Ga and In in HS deposits. Although this link requires more rigorous testing, we suggest that the presence of carbonaceous sedimentary rocks in the stratigraphic sequence hosting a HS deposit could provide a first-order exploration indicator for potential critical element mineralization.

\subsection{Concluding Remarks and Future Developments}

In summary, the evidence from this study and from the literature highlight the potential for various styles of $\mathrm{Ge}, \mathrm{Ga}$ and In mineralization in high-sulfidation epithermal deposits, as well as in the closely related intermediate-sulfidation epithermal deposits. This is something that is seldom considered during exploration and mining in these environments. In addition to their well-known resources of precious and base metals, the potential for critical elements could increase the prospectivity of these deposits.

Holistic mineralogical studies of similar deposits elsewhere, including more trace element data for common ore and alteration minerals, can help improve our understanding of the distribution of Ge, Ga and In in the epithermal environment. Data are particularly limited for deposits affected by supergene processes. To improve exploration for these commodities, a better understanding of the source(s) as well as the mechanisms of enrichment, transport and deposition of Ge, Ga and In in epithermal systems is also needed. We find the potential link between critical element enrichment and carbonaceous sedimentary rocks particularly interesting and deserving of more detailed investigation.

Supplementary Materials: The following are available online at www.mdpi.com/2075-163X/7/11/213/s1, Table S1: LA-ICP-MS data for sulfates and silicates from Mt Carlton, Table S2: WDS data for argyrodite from Mt Carlton, Table S3: LA-ICP-MS data for sulfides and sulfosalts from Mt Carlton, Table S4: LA-ICP-MS data for enargite from reference localities.

Acknowledgments: This research was funded by Evolution Mining and the Geological Survey of Queensland (GSQ). We thank the staff at the Mt Carlton mine for allowing us to collect the samples used in this study. Kevin Blake and Yi Hu at the Advanced Analytical Centre (AAC) at James Cook University are gratefully acknowledged for their technical assistance during the EPMA and LA-ICP-MS analyses, respectively. We appreciate constructive comments from three anonymous reviewers, which have helped us to improve this manuscript.

Author Contributions: Fredrik Sahlström and Antonio Arribas conceived the research within the framework of Fredrik Sahlström's PhD project. Fredrik Sahlström, Antonio Arribas and Isaac Corral acquired the samples. Fredrik Sahlström performed all analytical work, interpreted the data and wrote the paper, with contributions from Antonio Arribas, Paul Dirks, Isaac Corral and Zhaoshan Chang.

Conflicts of Interest: The authors declare no conflict of interest.

\section{References}

1. Schwarz-Schampera, U.; Herzig, P.M. Indium: Geology, Mineralogy, and Economics; Springer: Heidelberg, Germany, 2002.

2. Frenzel, M.; Hirsch, T.; Gutzmer, J. Gallium, germanium, indium, and other trace and minor elements in sphalerite as a function of deposit type-A meta-analysis. Ore Geol. Rev. 2016, 76, 52-78. [CrossRef]

3. Guberman, D. Germanium. In US Geological Survey Mineral Commodity Summaries; US Geological Survey: Reston, VA, USA, 2017; pp. 70-71. Available online: https://minerals.usgs.gov/minerals/pubs/commodity/ germanium/mcs-2017-germa.pdf (accessed on 15 September 2017).

4. Jaskula, B. Gallium. In US Geological Survey Mineral Commodity Summaries; US Geological Survey: Reston, VA, USA, 2017; pp. 64-65. Available online: https:/ / minerals.usgs.gov/minerals/pubs/commodity/gallium/ mcs-2017-galli.pdf (accessed on 15 September 2017).

5. Tolcin, A.C. Indium. In US Geological Survey Mineral Commodity Summaries; US Geological Survey: Reston, VA, USA, 2017; pp. 80-81. Available online: https://minerals.usgs.gov/minerals/pubs/commodity/indium/ mcs-2017-indiu.pdf (accessed on 15 September 2017).

6. Erdmann, L.; Graedel, T.E. Criticality of non-fuel minerals: A review of major approaches and analyses. Environ. Sci. Technol. 2011, 45, 7620-7630. [CrossRef] [PubMed] 
7. Höll, R.; Kling, M.; Schroll, E. Metallogenesis of germanium-A review. Ore Geol. Rev. 2007, 30, 145-180. [CrossRef]

8. Paradis, S. Indium, germanium and gallium in volcanic and sediment-hosted base-metal sulphide deposits. In Proceedings of the Symposium on Critical and Strategic Materials, Victoria, BC, Canada, 13-14 November 2015; Simandl, G.J., Neetz, M., Eds.; British Columbia Ministry of Energy and Mines: Victoria, BC, Canada, 2015; pp. 23-29.

9. Bernstein, L.R. Germanium geochemistry and mineralogy. Geochim. Cosmochim. Acta 1985, 49, $2409-2422$. [CrossRef]

10. Cook, N.J.; Ciobanu, C.L. Mineral hosts for critical metals in hydrothermal ores. In Mineral Resources in a Sustainable World, Proceedings of the 13th SGA Biennial Meeting, Nancy, France, 24-27 August 2015; André-Meyer, A.S., Cathelineau, M., Muchez, P.H., Pirard, E., Sindern, S., Eds.; Society for Geology Applied to Mineral Deposits: Geneva, Switzerland, 2015; pp. 707-710.

11. Ishihara, S.; Hoshino, K.; Murakami, H.; Endo, Y. Resource evaluation and some genetic aspects of indium in the Japanese ore deposits. Resour. Geol. 2006, 56, 347-364. [CrossRef]

12. Cook, N.J.; Ciobanu, C.L.; Williams, T. The mineralogy and mineral chemistry of indium in sulphide deposits and implications for mineral processing. Hydrometallurgy 2011, 108, 226-228. [CrossRef]

13. Frenzel, M.; Ketris, M.P.; Gutzmer, J. On the geological availability of germanium. Mineralium Deposita 2014, 49, 471-486. [CrossRef]

14. Frenzel, M.; Ketris, M.P.; Seifert, T.; Gutzmer, J. On the current and future availability of gallium. Resour. Policy 2016, 47, 38-50. [CrossRef]

15. Shimizu, T.; Morishita, Y. Petrography, chemistry, and near-infrared microthermometry of indium-bearing sphalerite from the Toyoha polymetallic deposit, Japan. Econ. Geol. 2012, 107, 723-735. [CrossRef]

16. Murakami, H.; Ishihara, S. Trace elements of indium-bearing sphalerite from tin-polymetallic deposits in Bolivia, China and Japan: A femto-second LA-ICPMS study. Ore Geol. Rev. 2013, 53, 223-243. [CrossRef]

17. Sillitoe, R.H.; Hedenquist, J.W. Linkages between volcanotectonic settings, ore-fluid compositions, and epithermal precious metal deposits. SEG Spec. Publ. 2003, 10, 315-343.

18. Simmons, S.F.; White, N.C.; John, D.A. Geological characteristics of epithermal precious and base metal deposits. In Economic Geology One Hundredth Anniversary Volume: 1905-2005; Hedenquist, J.W., Thompson, J.F.H., Goldfarb, R.J., Richards, J.P., Eds.; Society of Economic Geologists: Littleton, CO, USA, 2005; pp. 485-522.

19. Hedenquist, J.W.; Simmons, S.F.; Giggenbach, W.F.; Eldridge, C.S. White Island, New Zealand, volcanic-hydrothermal system represents the geochemical environment of high-sulfidation $\mathrm{Cu}$ and $\mathrm{Au}$ ore deposition. Geology 1993, 21, 731-734. [CrossRef]

20. Arribas, A. Characteristics of high-sulfidation epithermal deposits, and their relation to magmatic fluid. Miner. Assoc. Can. 1995, 23, 419-454.

21. Sillitoe, R.H. Gold-rich porphyry deposits: Descriptive and genetic models and their role in exploration and discovery. Rev. Econ. Geol. 2000, 13, 315-345.

22. Hedenquist, J.W.; Arribas, A.; Gonzalez-Urien, E. Exploration for epithermal gold deposits. Rev. Econ. Geol. 2000, 13, 245-277.

23. Sillitoe, R.H. Porphyry copper systems. Econ. Geol. 2010, 105, 3-41. [CrossRef]

24. Chang, Z.; Hedenquist, J.W.; White, N.C.; Cooke, D.R.; Roach, M.; Deyell, C.L.; Garcia, J.; Gemmell, J.B.; McKnight, S.; Cuison, A.L. Exploration tools for linked porphyry and epithermal deposits: Example from the Mankayan intrusion-centered Cu-Au district, Luzon, Philippines. Econ. Geol. 2011, 106, 1365-1398. [CrossRef]

25. Hedenquist, J.W. Mineralization associated with volcanic-related hydrothermal systems in the Circum-Pacific Basin. In Proceedings of the 4th Circum-Pacific Energy and Mineral Resources Conference, Singapore, 17-22 August 1986; American Association of Petroleum Geologists: Tulsa, OK, USA, 1986; pp. 513-524.

26. Einaudi, M.T.; Hedenquist, J.W.; Inan, E.E. Sulfidation state of fluids in acti ve and extinct hydrothermal systems: Transitions from porphyry to epithermal environments. SEG Spec. Publ. 2003, 10, 285-314.

27. Jannas, R.R.; Beane, R.E.; Ahler, B.A.; Brosnahan, D.R. Gold and copper mineralization at the El Indio deposit, Chile. J. Geochem. Explor. 1990, 36, 233-266. [CrossRef] 
28. Arribas, A.; Hedenquist, J.W.; Itaya, T.; Okada, T.; Concepción, R.A.; Garcia, J.S. Contemporaneous formation of adjacent porphyry and epithermal $\mathrm{Cu}$-Au deposits over $300 \mathrm{ka}$ in northern Luzon, Philippines. Geology 1995, 23, 337-340. [CrossRef]

29. Hedenquist, J.W.; Arribas, A.; Reynolds, T.J. Evolution of an intrusion-centered hydrothermal system: Far Southeast-Lepanto porphyry and epithermal Cu-Au deposits, Philippines. Econ. Geol. 1998, 93, 373-404. [CrossRef]

30. Sahlström, F.; Dirks, P.; Chang, Z.; Arribas, A.; Corral, I.; Obiri-Yeboah, M.; Hall, C. The Paleozoic Mt Carlton deposit, Bowen Basin, NE Australia: Shallow high-sulfidation epithermal Au-Ag-Cu mineralization formed during rifting. Econ. Geol. 2018. (under review).

31. Donchak, P.; Purdy, D.J.; Withnall, I.; Blake, P.; Jell, P.A. New England Orogen. In Geology of Queensland; Jell, P.A., Ed.; Geological Survey of Queensland: Brisbane, Australia, 2013; pp. 305-472.

32. Hutton, L.; Withnall, I.; Rienks, I.; Bultitude, R.J.; Hayward, M.; von Gneilinski, F.; Fordham, B.; Simpson, G. A preliminary Carboniferous to Permian magmatic framework for the Auburn and Connors Arches, central Queensland. In Proceedings of the 1999 New England Orogen Conference, Armidale, Australia, 1-3 February 1999; pp. 223-232.

33. Esterle, J.S.; Sliwa, R.; Smith, G.L.B.; Yago, J.V.R.; Williams, R.; Li, S.; Dimitrakopoulos, R. Bowen Basin Supermodel 2000; CSIRO Exploration \& Mining: Kenmore, Australia, 2002.

34. Korsch, R.; Totterdell, J.; Cathro, D.; Nicoll, M. Early Permian east Australian rift system. Aust. J. Earth Sci. 2009, 56, 381-400. [CrossRef]

35. Malone, E.J.; Olgers, F.; Kirkegaard, A. The Geology of the Duaringa and Saint-Lawrence 1:250,000 Sheet Areas, Queensland; Bureau of Mineral Resources: Canberra, Australia, 1969.

36. Allen, J.P.; Fielding, C.R. Sequence architecture within a low-accommodation setting: An example from the Permian of the Galilee and Bowen basins, Queensland, Australia. AAPG Bull. 2007, 91, 1503-1539. [CrossRef]

37. Korsch, R.; Totterdell, J. Subsidence history and basin phases of the Bowen, Gunnedah and Surat Basins, eastern Australia. Aust. J. Earth Sci. 2009, 56, 335-353. [CrossRef]

38. Fielding, C.; Falkner, A.; Kassan, J.; Draper, J. Permian and Triassic depositional systems in the Bowen Basin. In Proceedings of the Bowen Basin Symposium, Mackay, Australia, 1990; Beeston, J.W., Ed.; Geological Society of Australia-Queensland Division: Brisbane, Australia, 1990; pp. 21-25.

39. Fergusson, C.L. Thin-skinned thrusting in the northern New England Orogen, central Queensland, Australia. Tectonics 1991, 10, 797-806. [CrossRef]

40. Holcombe, R.; Stephens, C.; Fielding, C.; Gust, D.; Little, T.; Sliwa, R.; Kassan, J.; McPhie, J.; Ewart, A. Tectonic evolution of the northern New England Fold Belt: The Permian-Triassic Hunter-Bowen event. In Tectonics and Metallogenesis of the New England Orogen; Ashley, P.M., Flood, P.G., Eds.; Geological Society of Australia: Sydney, Australia, 1997; pp. 52-65.

41. Corral, I.; Chang, Z.; Dirks, P.H.G.M.; Sahlström, F.; Behnsen, H.; Hall, C.; Creaser, R. The Capsize prospect (NE Queensland, Australia): Geology, geochemistry and geochronology of a multipulse rhyolite-driven porphyry and associated lithocap. (unpublished; manuscript in preparation).

42. Sahlström, F.; Blake, K.; Corral, I.; Chang, Z. Hyperspectral cathodoluminescence study of indium-bearing sphalerite from the Mt Carlton high-sulphidation epithermal deposit, Queensland, Australia. Eur. J. Mineral. 2017, in press. [CrossRef]

43. Ohta, E. Occurrence and chemistry of indium-containing minerals from the Toyoha mine, Hokkaido, Japan. Min. Geol. 1989, 39, 355-371. [CrossRef]

44. Sinclair, W.; Kooiman, G.; Martin, D.; Kjarsgaard, I. Geology, geochemistry and mineralogy of indium resources at Mount Pleasant, New Brunswick, Canada. Ore Geol. Rev. 2006, 28, 123-145. [CrossRef]

45. Murillo, F.; Sanjinés, O.; Barrera, L.; Jiménez, N.; Lizeca, J.; Flores, O.; Hoffstra, A.; Hardyman, R.; Nash, T. Geología, alteración, y mineralización del depósito mineral tipo sulfato-ácido de Laurani, Altiplano Norte de Bolivia. In Investigaciones de Metales Preciosos en el Complejo Volcánico Neógeno-Cuaternario de los Andes Centrales; Servicio Geológico de Bolivia: La Paz, Bolivia, 1993; pp. 123-130.

46. Losada-Calderón, A.; McPhail, D. Porphyry and high-sulfidation epithermal mineralization in the Nevados del Famatina mining district, Argentina. SEG Spec. Publ. 1996, 5, 91-118.

47. Perelló, J. Geology, porphyry $\mathrm{Cu}-\mathrm{Au}$, and epithermal $\mathrm{Cu}-\mathrm{Au}-\mathrm{Ag}$ mineralization of the Tombulilato district, North Sulawesi, Indonesia. J. Geochem. Explor. 1994, 50, 221-256. [CrossRef] 
48. Chambefort, I. The Cu-Au Chelopech Deposit, Panagyurishte District, Bulgaria: Volcanic Setting, Hydrothermal Evolution and Tectonic Overprint of a Late Cretaceous High-Sulfidation Epithermal Deposit. Ph.D. Thesis, University of Geneva, Geneva, Switzerland, 2005.

49. Corral, I.; Cardellach, E.; Corbella, M.; Canals, À.; Gómez-Gras, D.; Griera, A.; Cosca, M.A. Cerro Quema (Azuero Peninsula, Panama): Geology, alteration, mineralization, and geochronology of a volcanic dome-hosted high-sulfidation Au-Cu deposit. Econ. Geol. 2016, 111, 287-310. [CrossRef]

50. Gustafson, L.B.; Hunt, J.P. The porphyry copper deposit at El Salvador, Chile. Econ. Geol. 1975, 70, 857-912. [CrossRef]

51. Jochum, K.P.; Weis, U.; Stoll, B.; Kuzmin, D.; Yang, Q.; Raczek, I.; Jacob, D.E.; Stracke, A.; Birbaum, K.; Frick, D.A. Determination of reference values for NIST SRM 610-617 glasses following ISO guidelines. Geostand. Geoanal. Res. 2011, 35, 397-429. [CrossRef]

52. Jochum, K.P.; Willbold, M.; Raczek, I.; Stoll, B.; Herwig, K. Chemical characterisation of the USGS reference glasses GSA-1G, GSC-1G, GSD-1G, GSE-1G, BCR-2G, BHVO-2G and BIR-1G using EPMA, ID-TIMS, ID-ICP-MS and LA-ICP-MS. Geostand. Geoanal. Res. 2005, 29, 285-302. [CrossRef]

53. Wilson, S.; Ridley, W.; Koenig, A. Development of sulfide calibration standards for the laser ablation inductively-coupled plasma mass spectrometry technique. J. Anal. At. Spectrom. 2002, 17, 406-409. [CrossRef]

54. Van Achterbergh, E.; Ryan, C.; Jackson, S.; Griffin, W. GLITTER: data reduction software for LA-ICP-MS. Mineral. Assoc. Can. 2001, 29, 239-243.

55. Rye, R.O.; Bethke, P.M.; Wasserman, M.D. The stable isotope geochemistry of acid sulfate alteration. Econ. Geol. 1992, 87, 225-262. [CrossRef]

56. Rye, R.O. A review of the stable-isotope geochemistry of sulfate minerals in selected igneous environments and related hydrothermal systems. Chem. Geol. 2005, 215, 5-36. [CrossRef]

57. Tananaev, I.; Kuznetsov, V.; Bolshakova, N. Basic gallium salts of the alunite type. Russ. J. Inorg. Chem. 1967, $12,28-30$.

58. Jambor, J.L.; Owens, D.R.; Grice, J.D.; Feinglos, M.N. Gallobeudantite, $\mathrm{PbGa}_{3}\left[\left(\mathrm{AsO}_{4}\right),\left(\mathrm{SO}_{4}\right)\right]_{2}(\mathrm{OH})_{6}$, a new mineral species from Tsumeb, Namibia, and associated new gallium analogues of the alunite-jarosite family. Can. Mineral. 1996, 34, 1305-1315.

59. Jambor, J.L. Nomenclature of the alunite supergroup. Can. Mineral. 1999, 37, 1323-1342.

60. Dutrizac, J.; Chen, T. The behaviour of gallium during jarosite precipitation. Can. Metall. Q. 2000, 39, 1-14. [CrossRef]

61. Weisbach, A. Argyrodit, ein neues silbererz. Neues Jahrbuch für Mineralogie Geologie und Palaontologie 1886, 2, 67-71.

62. Paar, W.H.; Roberts, A.C.; Berlepsch, P.; Armbruster, T.; Topa, D.; Zagler, G. Putzite, $\left(\mathrm{Cu}_{4.7} \mathrm{Ag}_{3.3}\right) \sum_{8} \mathrm{GeS}_{6}$, a new mineral species from Capillitas, Catamarca, Argentina. Description and crystal structure. Can. Mineral. 2004, 42, 1757-1769. [CrossRef]

63. De Ronde, C.E.; Massoth, G.J.; Butterfield, D.A.; Christenson, B.W.; Ishibashi, J.; Ditchburn, R.G.; Hannington, M.D.; Brathwaite, R.L.; Lupton, J.E.; Kamenetsky, V.S. Submarine hydrothermal activity and gold-rich mineralization at Brothers Volcano, Kermadec Arc, New Zealand. Mineralium Deposita 2011, 46, 541-584. [CrossRef]

64. Gonzalez, A. Geology and Genesis of the Lepanto Copper Deposit, Mankayan, Mountain Province, Philippines. Ph.D. Thesis, Stanford University, Stanford, CA, USA, 1959.

65. Deyell, C.; Hedenquist, J. Trace element geochemistry of enargite in the Mankayan district, Philippines. Econ. Geol. 2011, 106, 1465-1478. [CrossRef]

66. Arribas, A.; Cunningham, C.G.; Rytuba, J.J.; Rye, R.O.; Kelly, W.C.; Podwysocki, M.H.; McKee, E.H.; Tosdal, R.M. Geology, geochronology, fluid inclusions, and isotope geochemistry of the Rodalquilar gold alunite deposit, Spain. Econ. Geol. 1995, 90, 795-822. [CrossRef]

67. Martín-Vivaldi, J.; Sierra, J.; Leal, J. Some aspects of the mineralization and wall-rock alteration in the Rodalquilar goldfield, SE Spain. Soc. Min. Geol. Jpn. Spec. Issue 1971, 2, 145-152.

68. Reich, M.; Kesler, S.E.; Utsunomiya, S.; Palenik, C.S.; Chryssoulis, S.L.; Ewing, R.C. Solubility of gold in arsenian pyrite. Geochim. Cosmochim. Acta 2005, 69, 2781-2796. [CrossRef]

69. Cook, N.J.; Ciobanu, C.L.; Pring, A.; Skinner, W.; Shimizu, M.; Danyushevsky, L.; Saini-Eidukat, B.; Melcher, F. Trace and minor elements in sphalerite: A LA-ICPMS study. Geochim. Cosmochim. Acta 2009, 73, 4761-4791. [CrossRef] 
70. Johan, Z. Indium and germanium in the structure of sphalerite: An example of coupled substitution with copper. Mineral. Petrol. 1988, 39, 211-229. [CrossRef]

71. Cook, N.J.; Sundblad, K.; Valkama, M.; Nygård, R.; Ciobanu, C.L.; Danyushevsky, L. Indium mineralisation in A-type granites in southeastern Finland: Insights into mineralogy and partitioning between coexisting minerals. Chem. Geol. 2011, 284, 62-73. [CrossRef]

72. Cook, N.J.; Ciobanu, C.L.; Brugger, J.; Etschmann, B.; Howard, D.L.; de Jonge, M.D.; Ryan, C.; Paterson, D. Determination of the oxidation state of $\mathrm{Cu}$ in substituted $\mathrm{Cu}$-In-Fe-bearing sphalerite via $\mu$-XANES spectroscopy. Am. Mineral. 2012, 97, 476-479. [CrossRef]

73. Bonnet, J. Distribution et Contrôle Cristallographique des Éléments Ge, Ga et Cd dans les Sphalérites des Gisements de Type Mississippi Valley dans les Districts de Central et East Tennessee, USA. Ph.D. Thesis, University of Lorraine, Lorraine, France, 2014.

74. Cook, N.J.; Etschmann, B.; Ciobanu, C.L.; Geraki, K.; Howard, D.L.; Williams, T.; Rae, N.; Pring, A.; Chen, G.; Johannessen, B. Distribution and substitution mechanism of Ge in a Ge-(Fe)-bearing sphalerite. Minerals 2015, 5, 117-132. [CrossRef]

75. Belissont, R.; Muñoz, M.; Boiron, M.-C.; Luais, B.; Mathon, O. Distribution and oxidation state of Ge, Cu and Fe in sphalerite by $\mu$-XRF and K-edge $\mu$-XANES: Insights into Ge incorporation, partitioning and isotopic fractionation. Geochim. Cosmochim. Acta 2016, 177, 298-314. [CrossRef]

76. George, L.; Cook, N.J.; Cristiana, L.; Wade, B.P. Trace and minor elements in galena: A reconnaissance LA-ICP-MS study. Am. Mineral. 2015, 100, 548-569. [CrossRef]

77. Di Benedetto, F.; Pelo, S.D.; Caneschi, A.; Lattanzi, P. Chemical state of arsenic and copper in enargite: Evidences from EPR and X-ray absorption spectroscopies, and SQUID magnetometry. J. Mineral. Geochem. 2011, 188, 11-19. [CrossRef]

78. Mills, S.J.; Kampf, A.R.; Raudsepp, M.; Christy, A. The crystal structure of Ga-rich plumbogummite from Tsumeb, Namibia. Mineral. Mag. 2009, 73, 837-845. [CrossRef]

79. Dutrizac, J.; Jambor, J.; Chen, T. Host minerals for the gallium-germanium ores of the Apex Mine, Utah. Econ. Geol. 1986, 81, 946-950. [CrossRef]

80. Bernstein, L.R. Geology and mineralogy of the Apex germanium-gallium mine, Washington County, Utah. USGS Bull. 1986, 1577, 1-9.

81. Schulte, R.F.; Foley, N.K. Compilation of gallium resource data for bauxite deposits. In USGS Open-File Report 2013-1272; US Geological Survey: Reston, VA, USA, 2014. [CrossRef]

82. Rytuba, J.J.; John, D.A.; Foster, A.; Ludington, S.D.; Kotlyar, B. Chapter C: Hydrothermal enrichment of gallium in zones of advanced argillic alteration-Examples from the Paradise Peak and McDermitt ore deposits, Nevada. In Contributions to Industrial Minerals Research-US Geological Survey Bulletin nr. 2209; Bliss, J.D., Moyle, P.R., Long, K.R., Eds.; US Geological Survey: Reston, VA, USA, 2003.

83. Cunningham, C.G.; Rye, R.O.; Steven, T.A.; Mehnert, H.H. Origins and exploration significance of replacement and vein-type alunite deposits in the Marysvale volcanic field, west central Utah. Econ. Geol. 1984, 79, 50-71. [CrossRef]

84. Bove, D.J.; Rye, R.O.; Hon, K. Evolution of the Red Mountain alunite deposit, Lake City, Colorado. In US Geological Survey Open-File Reports 90-235; US Geological Survey: Reston, VA, USA, 1990. Available online: https:/ / pubs.er.usgs.gov/publication/ofr90235 (accessed on 19 August 2017).

85. Asahi Chemical Industry, Ltd. Method for the Recovery of Gallium from Alunite. U.S. Patent US3,168,372 A, 1965.

86. Zijin Mining Group, Ltd. Method for Recycling Gallium in Alunite Concentrate. Patent CN102,517,461 A, 2012.

87. Lombaard, A.; Günzel, A.; Innes, J.; Krüger, T. The Tsumeb lead-copper-zinc-silver deposit, south west Africa/Namibia. In Mineral Deposits of Southern Africa; Anhaeusser, C.R., Maske, S., Eds.; Geological Society of South Africa: Johannesburg, South Africa, 1986; pp. 1761-1787.

88. Melcher, F; Oberthür, T.; Rammlmair, D. Geochemical and mineralogical distribution of germanium in the Khusib Springs $\mathrm{Cu}-\mathrm{Zn}-\mathrm{Pb}-\mathrm{Ag}$ sulfide deposit, Otavi Mountain Land, Namibia. Ore Geol. Rev. 2006, 28, 32-56. [CrossRef]

89. Terziev, G. The conditions of germanium accumulation in hydrothermal mineralization (as illustrated by a Bulgarian copper-pyrite deposit). Geochem. Int. 1966, 3, 341-346. 
90. Terziev, G. Mineral composition and genesis of the Chelopech ore deposit. Geokhim. Mineral. Petrol. 1968, 17, 123-187.

91. Kovalenker, V.; Tsonev, D.; Breskovska, V.; Malov, V.; Troneva, N. New data on the mineralogy of the massive-sulphide deposits in the Central Srednogorie of Bulgaria. In Metasomatism, Mineralogy and Genesis of Gold and Silver Deposits in Volcanic Series; Nauka: Moscow, Russia, 1986; pp. 91-110.

92. Petrunov, R. Ore mineral parageneses and zoning in the deposit of Chelopech. Geokhim. Mineral. Petrol. 1995, 30, 89-98.

93. Bonev, I.K.; Kerestedjian, T.; Atanassova, R.; Andrew, C.J. Morphogenesis and composition of native gold in the Chelopech volcanic-hosted $\mathrm{Au}-\mathrm{Cu}$ epithermal deposit, Srednogorie zone, Bulgaria. Mineralium Deposita 2002, 37, 614-629. [CrossRef]

94. Bogdanov, K.; Tsonev, D.; Popov, K. Mineral assemblages and genesis of the Cu-Au epithermal deposits in the southern part of the Panaguyrishte Ore District, Bulgaria. Bull. Geol. Soc. Greece 2004, 36, 406-415.

95. Tămaş, C.G.; Bailly, L.; Ghergari, L.; O'Connor, G.; Minuţ, A. New occurrences of tellurides and argyrodite in Roşia Montană, Apuseni Mountains, Romania, and their metallogenic significance. Can. Mineral. 2006, 44, 367-383. [CrossRef]

96. Putz, H.; Paar, W.H.; Topa, D. A contribution to the knowledge of the mineralization at Mina Capillitas, Catamarca. Rev. Asoc. Geol. Argent. 2009, 64, 514-524.

97. Putz, H.; Paar, W.H.; Sureda, R.; Roberts, A. Germanium mineralization at Capillitas, Catamarca Province, Argentina. In Proceedings of the 18th General Meeting of the IMA, Edinburgh, Scotland, 1-6 September 2002.

98. Paar, W.H.; Putz, H. Germanium associated with epithermal mineralization: Examples from Bolivia and Argentina. In Mineral Deposit Research: Meeting the Global Challenge, Proceedings of the 8th Biennial SGA Meeting, Beijing, China, 18-21 August 2005; Mao, J., Bierlein, F.P., Eds.; Society for Geology Applied to Mineral Deposits: Geneva, Switzerland, 2005; pp. 48-51.

99. Putz, H.; Paar, W.H.; Topa, D.; Makovicky, E.; Roberts, A.C. Catamarcaite, $\mathrm{Cu}_{6} \mathrm{GeWS}_{8}$, a new germanium sulfide mineral species from Capillitas, Catamarca, Argentina: Description, paragenesis and crystal structure. Can. Mineral. 2006, 44, 1481-1497. [CrossRef]

100. Bindi, L.; Putz, H.; Paar, W.H.; Stanley, C. Omariniite, $\mathrm{Cu}_{8} \mathrm{Fe}_{2} \mathrm{ZnGe}_{2} \mathrm{~S}_{12}$, the germanium-analogue of stannoidite, a new mineral species from Capillitas, Argentina. Mineral. Mag. 2017, 81, 1151-1159. [CrossRef]

101. Maydagán, L.; Franchini, M.; Lentz, D.; Pons, J.; McFarlane, C. Sulfide composition and isotopic signature of the Altar $\mathrm{Cu}$-Au deposit, Argentina: Constraints on the evolution of the porphyry-epithermal system. Can. Mineral. 2013, 51, 813-840. [CrossRef]

102. Dekov, V.M.; Rouxel, O.; Kouzmanov, K.; Bindi, L.; Asael, D.; Fouquet, Y.; Etoubleau, J.; Burgaud, G.; Wälle, M. Enargite-luzonite hydrothermal vents in Manus Back-Arc Basin: Submarine analogues of high-sulfidation epithermal mineralization. Chem. Geol. 2016, 438, 36-57. [CrossRef]

103. Lane, D.J.; Cook, N.J.; Grano, S.R.; Ehrig, K. Selective leaching of penalty elements from copper concentrates: A review. Miner. Eng. 2016, 98, 110-121. [CrossRef]

104. Dill, H.G.; Garrido, M.M.; Melcher, F.; Gomez, M.C.; Weber, B.; Luna, L.I.; Bahr, A. Sulfidic and non-sulfidic indium mineralization of the epithermal $\mathrm{Au}-\mathrm{Cu}-\mathrm{Zn}-\mathrm{Pb}-\mathrm{Ag}$ deposit San Roque (Provincia Rio Negro, SE Argentina) -With special reference to the "indium window" in zinc sulfide. Ore Geol. Rev. 2013, 51, 103-128. [CrossRef]

105. Lopez, L.; Jovic, S.M.; Guido, D.M.; Vidal, C.P.; Páez, G.N.; Ruiz, R. Geochemical distribution and supergene behavior of indium at the Pingüino epithermal polymetallic vein system, Patagonia, Argentina. Ore Geol. Rev. 2015, 64, 747-755. [CrossRef]

106. Wood, S.A.; Samson, I.M. The aqueous geochemistry of gallium, germanium, indium and scandium. Ore Geol. Rev. 2006, 28, 57-102. [CrossRef]

107. Belissont, R.; Boiron, M.-C.; Luais, B.; Cathelineau, M. LA-ICP-MS analyses of minor and trace elements and bulk Ge isotopes in zoned Ge-rich sphalerites from the Noailhac-Saint-Salvy deposit (France): Insights into incorporation mechanisms and ore deposition processes. Geochim. Cosmochim. Acta 2014, 126, 518-540. [CrossRef] 
108. Belissont, R.; Boiron, M.C.; Luais, B.; Muchez, P.; de Oliveira, D.P.; Muñoz, M. Germanium distribution and isotopic study in sulphides from MVT-related and VMS-remobilised ore deposits. In Mineral Resources in a Sustainable World, Proceedings of the 13th SGA Biennial Meeting, Nancy, France, 24-27 August 2015; André-Meyer, A.S., Cathelineau, M., Muchez, P.H., Pirard, E., Sindern, S., Eds.; Society for Geology Applied to Mineral Deposits: Geneva, Switzerland, 2015; pp. 683-686.

109. Driesner, T.; Pintea, I. Constraints on the conditions of wurtzite formation at the Agios Philippos Pb-Zn deposit, NE-Greece. Eur. J. Mineral. 1994, 6, 54.

110. Skarpelis, N. Minor elements in the base metal part of an epithermal system: The Kirki (St. Philippe) Mine, Thrace, Northern Greece. In Proceedings of the 8th EUG Meeting, Strasbourg, France, 9-13 April 1995; p. 293.

111. Melfos, V.; Voudouris, P. Geological, mineralogical and geochemical aspects for critical and rare metals in Greece. Minerals 2012, 2, 300-317. [CrossRef]

112. Tămaş, C.G.; Grobety, B.; Bailly, L.; Bernhardt, H.-J.; Minuţ, A. Alburnite, $\mathrm{Ag}_{8} \mathrm{GeTe}_{2} \mathrm{~S}_{4}$, a new mineral species from the Roşia Montana Au-Ag epithermal deposit, Apuseni Mountains, Romania. Am. Mineral. 2014, 99, 57-64. [CrossRef]

113. Márquez-Zavalía, M.F.; Galliski, M.Á.; Drábek, M.; Vymazalová, A.; Watanabe, Y.; Murakami, H.; Bernhardt, H.-J. Ishiharaite, $(\mathrm{Cu}, \mathrm{Ga}, \mathrm{Fe}, \mathrm{In}, \mathrm{Zn}) \mathrm{S}$, a new mineral from the Capillitas mine, northwestern Argentina. Can. Mineral. 2014, 52, 969-980. [CrossRef]

114. Carrillo-Rosúa, J.; Morales-Ruano, S.; Hach-Alí, P.F. Textural and chemical features of sphalerite from the Palai-Islica deposit (SE Spain): Implications for ore genesis and color. J. Mineral. Geochem. 2008, 185, 63-78. [CrossRef]

115. Symonds, R.B.; Rose, W.I.; Reed, M.H.; Lichte, F.E.; Finnegan, D.L. Volatilization, transport and sublimation of metallic and non-metallic elements in high temperature gases at Merapi Volcano, Indonesia. Geochim. Cosmochim. Acta 1987, 51, 2083-2101. [CrossRef]

116. Kavalieris, I. High Au, Ag, Mo, Pb, V and $\mathrm{W}$ content of fumarolic deposits at Merapi Volcano, central Java, Indonesia. J. Geochem. Explor. 1994, 50, 479-491. [CrossRef]

117. Kovalenker, V.; Laputina, I.; Znamenskii, V.; Zotov, I. Indium mineralization of the Great Kuril Island arc. Geol. Ore Depos. 1993, 35, 547-552.

118. Taran, Y.A.; Hedenquist, J.H.; Korzhinsky, M.; Tkachenko, S.; Shmulovich, K. Geochemistry of magmatic gases from Kudryavy Volcano, Iturup, Kuril Islands. Geochim. Cosmochim. Acta 1995, 59, 1749-1761. [CrossRef]

119. De Ronde, C.E.; Hannington, M.; Stoffers, P.; Wright, I.; Ditchburn, R.; Reyes, A.; Baker, E.; Massoth, G.; Lupton, J.; Walker, S. Evolution of a submarine magmatic-hydrothermal system: Brothers Volcano, southern Kermadec arc, New Zealand. Econ. Geol. 2005, 100, 1097-1133. [CrossRef]

120. Breiter, K.; Gardenová, N.; Kanický, V.; Vaculovič, T. Gallium and germanium geochemistry during magmatic fractionation and post-magmatic alteration in different types of granitoids: A case study from the Bohemian Massif (Czech Republic). Geol. Carpath. 2013, 64, 171-180. [CrossRef]

121. Ohta, E. Common features and genesis of tin-polymetallic veins. Resour. Geol. 1995, 18, 187-195.

122. Richards, J.P. The oxidation state, and sulfur and $\mathrm{Cu}$ contents of arc magmas: Implications for metallogeny. Lithos 2015, 233, 27-45. [CrossRef]

123. Breger, I.A.; Schopf, J.M. Germanium and uranium in coalified wood from upper Devonian black shale. Geochim. Cosmochim. Acta 1955, 7, 287-293. [CrossRef]

124. Shaw, D.M. The geochemistry of indium. Geochim. Cosmochim. Acta 1952, 2, 185-206. [CrossRef]

(C) 2017 by the authors. Licensee MDPI, Basel, Switzerland. This article is an open access article distributed under the terms and conditions of the Creative Commons Attribution (CC BY) license (http://creativecommons.org/licenses/by/4.0/). 